\title{
PROSPECÇ̃̃O DE ESTRUTURAS SUBTERRÂNEAS PARA PROCESSOS DE RECARGA INDIRETA DO AQÜÍFERO CÁRSTICO COM ÁGUAS DO RIO CAPIVARI - COLOMBRO, PR
}

\author{
Ernani Francisco da Rosa Filho ${ }^{1}$, Eduardo Chemas Hindi' ${ }^{1}$, Augustinho Rigoti², João Horácio \\ Pereira $^{3}$ e Marcos Justino Guarda ${ }^{3}$
}

\begin{abstract}
RESUMO
A região da "Várzea do Capivari, no município de Colombo-PR, está inserida nas denominadas "células aqüíferas cársticas", onde já existem 12 poços tubulares em operação cujo somatório das vazões é da ordem de $430 \mathrm{~L} / \mathrm{s}$. Embora a "problemática" da extração da água deste aqǘfero, com alguns locais sofrendo problemas de ordem geotécnica e ambiental, este manancial é fundamental para o abastecimento de Colombo. As rochas que constituem o sistema cárstico são representadas por mármores calcíticos e dolomíticos, intercalados por filitos e quartzitos, segundo a direção geral NE-SW. Sob a forma de intrusões, ocorrem diques de diabásio com direções NW-SE. O mapeamento da área, cobrindo $77 \mathrm{~km}^{2}$, foi feito na escala 1:20.000, com o auxílio de imagens de Satélite Lansat (Quick Bird), na resolução 040 m. A aplicação de métodos elétricos (caminhamento e SEV), com queda da resistividade elétrica, em arranjo dipolo-dipolo, permitiu localizar zonas carstificas em profundidades de até 50 $\mathrm{m}$, entre o rio Capivari e os pontos onde serão perfurados mais dois poços tubulares. A aplicação de cintilometria não identificou a presença de rochas graníticas em subsuperfície, sendo que a magnetometria identificou a presença de apenas um corpo de diabásio na área de estudo. As medições das descargas do rio Capivari, foram executadas a montante e a juzante da área onde serão perfurados os poços-testes; a diferença entre estes dois pontos foi de $1.191 \mathrm{~m}^{3} / \mathrm{h}$, incluindo a descarga do afluente ribeirão das Onças, da ordem de $392, \mathrm{~m}^{3} / \mathrm{h}$. Neste mesmo período, os três poços existentes na localidade, extraíram uma vazão de $302 \mathrm{~m}^{3} / \mathrm{h}$. Desconsiderando a contribuição deste afluente, resta uma descarga igual a $799 \mathrm{~m}^{3} / \mathrm{h}$ e, como $70 \%$ da descarga cooresponde a vazão de base, restaria $240 \mathrm{~m}^{3} / \mathrm{h}$ que poderá ser extraída através dos poços a serem implantados na área de estudo. As águas do rio Capivari são classificadas como sendo de Classe I.
\end{abstract}

\section{INTRODUÇ̃̃OO}

A região da "Várzea do Capivari, no município de Colombo-PR, também está inserida nas denominadas "células aqǘferas cársticas", onde foram executados 12 poços tubulares cujo somatório das vazões extraídas (da ordem de $430 \mathrm{~L} / \mathrm{s}$ ) é destinado ao abastecimento público de Colombo e das localidades vizinhas. A extração da água de alguns poços resultaram numa série de problemas de ordem geotécnica (acomodação do solo com conseqüentes rachaduras em casas e prédios das redondezas) e ambiental (redução das vazões de fontes naturais).

Embora toda essa problemática, o uso do "Karst" para o abastecimento público continua sendo uma importante alternativa sob o ponto de vista econômico, técnico e ambiental. A viabilização da extração de água deste aqüífero exige, de qualquer forma, que a taxa de bombeamento de cada poço seja feita desde que mantido o nível dinâmico da água numa posição acima das "cavidades" aqüíferas, sem diminuir, simultaneamente, a vazão de base da rede de drenagem da região.

\section{OBJETIVO}

O principal objetivo deste trabalho é representado pela delimitação de áreas adequadas aos processos de recarga induzida do rio Capivari ao aqüífero, através de estruturas carstificadas.

\section{RESULTADOS OBTIDOS}

$\mathrm{O}$ procedimento utilizado neste trabalho se baseou em levantamentos geológicos de detalhe e na aplicação de métodos geofísicos.

\section{Mapeamento litológico e geomorfológico de detalhe}

Esse mapeamento foi realizado na escala: 1:20.000. O objetivo deste mapeamento, no qual foi utilizado imagens de Satélite Landsat (Quick Bird) com resolução 0,40 m, cobriu uma área de $77 \mathrm{~km}^{2}$. Os resultados são apresentados na Figura 1.

O sistema cárstico da Formação Capiru do Grupo Açungui está diretamente ligado às características das suas rochas e dos seus aspectos morfológicos e estruturais. A água subterrânea, objeto deste trabalho, encontra-se armazenada em estruturas carstificadas que se desenvolveram em rochas carbonáticas e, assim sendo, o enfoque foi dado ao conjunto denominado "unidade de rochas metassedimentares do proterozóico paranaense" e

\footnotetext{
${ }^{1} L P H-D E G E O L-U F P R$

${ }^{2}$ Consultor da SANEPAR

${ }^{3}$ Geólogos da SANEPAR
} 
a "unidade litológica modificadora da morfologia e da configuração geológica da área", sendo estas representadas pelas intrusões de diques de rochas básicas, em especial de diabásios. As rochas carbonáticas são representadas por uma seqüência metassedimentar formada por mármores calcí ticos e dolomíticos intercalados a rochas de composição silicatada, como filitos e quartzitos, sendo que toda esta unidade litológica está orientada segundo a direção geral NE-SW. Os diques de diabásio, de idade Juro-cretácea, apresentam direção NW-SE e espaçamento médio entre um corpo e outro de até $1 \mathrm{~km}$. Estas rochas encontram-se verticalizadas e apresentam estrutura maciça que em profundidade chegam a alcançar centenas de metros. Os diques são praticamente impermeáveis e por esta razão possuem uma importância muito grande na configuração hidráulica do aqüífero.

Dentre as várias investigações geoestruturais e estratigráficas realizadas na região, destacam-se os trabalhos de Maack (1947), Bigarella e Salamuni (1956, 1958, 1959), Marini e Bigarella (1967), Marini (1970), Fuck et all. (1971), Fairchild (1977), Soares (1987), Fassbinder (1996) e CPRM (1998).

Com base nos aspectos litológicos, morfoestruturais, climáticos e hídricos, foi esboçada uma configuração espacial do referido sistema pelos geólogos Álvaro Amoretti Lisboa e Marco Aurélio Fontana, no ano de 1991. Esta configuração espacial foi publicada por Lisboa e Bonacim (1995), Lisboa (1997) e Rosa Filho et all.. (1996). De acordo com os autores mencionados, as unidades morfoestruturais referidas formam uma série de "tanques" interligados por vertedouros de topo através da drenagem superficial da bacia hidrográfica.

Trata-se de um aqüífero heterogêneo e anisotrópico e, portanto, o fluxo subterrâneo pode variar entre laminar e turbulento. Não existindo equações matemáticas que expliquem o comportamento do fluxo em meio carstificado, as estratégias que têm sido empregadas atualmente, mesmo em países com longa tradição de exploração neste tipo de reservatório subterrâneo, são feitas a partir de aproximações a partir do balanço hídrico e da decomposição de hidrogramas de rios e de nascentes naturais.

Através do manto de alteração das rochas carbonatadas, saturado com águas freáticas, é que ocorre a recarga difusa para os condutos principais do aqǘf́fero cárstico. Nas áreas de ocorrência das rochas carbonáticas, nas porções mais rebaixadas do terreno, se concentram as dolinas e até mesmo coalescências de duas ou mais dolinas que, em alguns casos, correspondem a estruturas de recarga direta no aqüífero.

\section{Métodos geofísicos}

A aplicação de métodos elétricos (caminhamento eSEV) foi utilizada para a detecção de estruturas carstificadas até profundidades de $50 \mathrm{~m}$, preferencialmente onde se estimava a ocorrência de conexão entre o rio Capivari com as áreas onde se pretende implantar novos poços tubulares.

A aplicação de cintilometria foi utilizada para identificar em sub-superfície a existência de corpos de rochas graníticas. Essas rochas apresentam distribuição espacial pouco previsível em profundidade e poderiam, portanto, de alguma forma obstruir o fluxo subterrâneo, localmente.

A aplicação da magnetometria foi utilizada para identificar as rochas de composição básica que são comuns na região, a exemplo dos diques de diabásios.

A conhecida resposta geoelétrica do carste, com queda da resistividade elétrica facilmente detectável, motivou a aplicação do caminhamento elétrico com arranjo dipolo-dipolo para mapeamento de dutos de dissolução que pudessem não só constituir aqüífero, mas que tivessem conectividade com o rio Capivari que meandra pela área de estudo, esperando-se que esta conectividade contribua significativamente para a recarga do aqǘf́rero. 


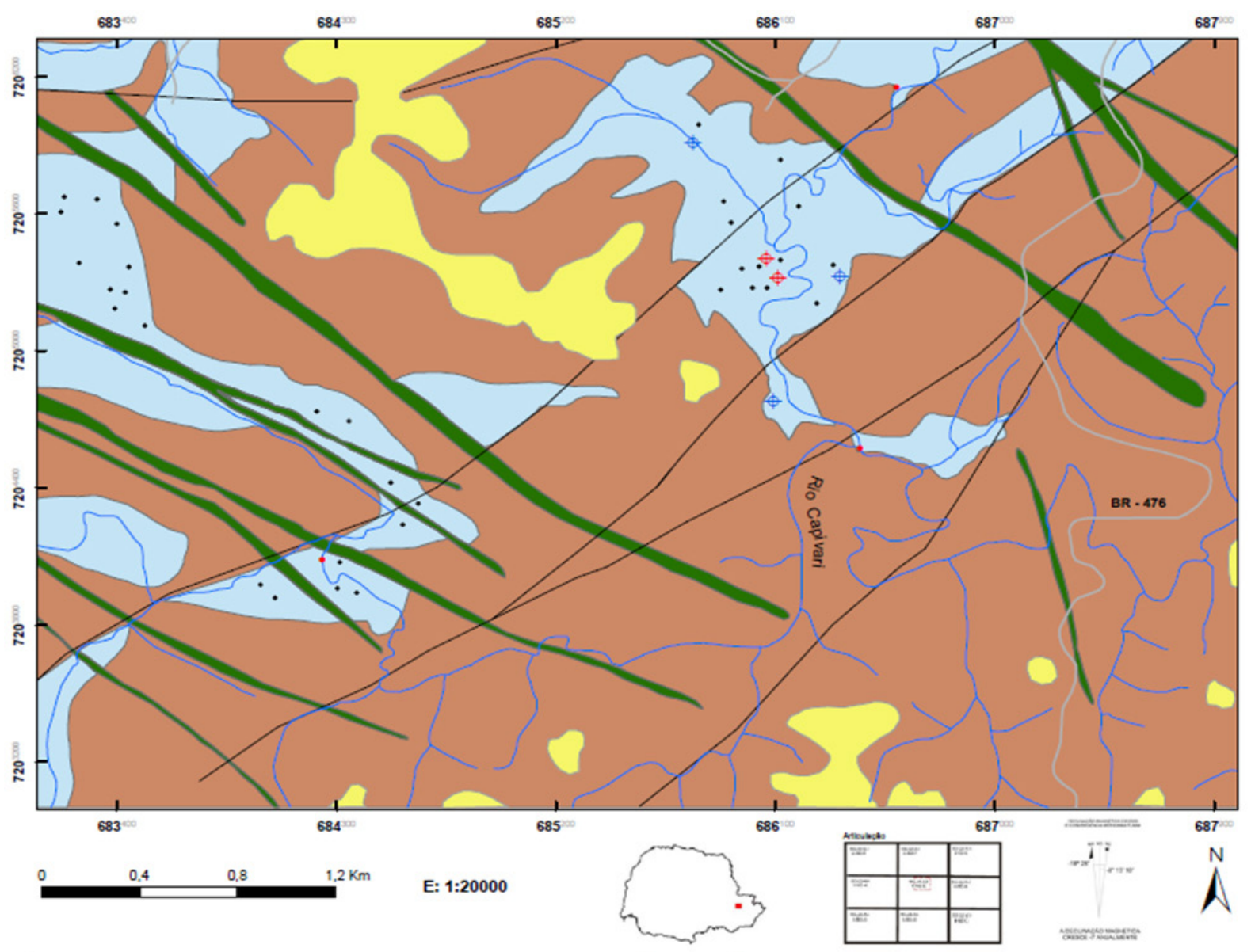

Legenda
Convenções

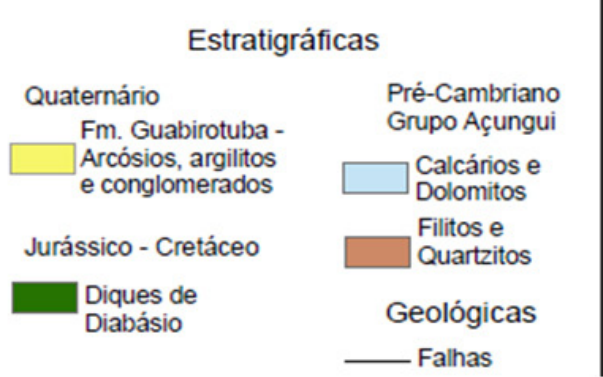

Hidrogeológicas

๑ Futuros Poços

4 Poços
Topográficas

— Rios

- Estradas

- Estaçōes

- Dolinas

Figura 1 - Mapa Litológico 


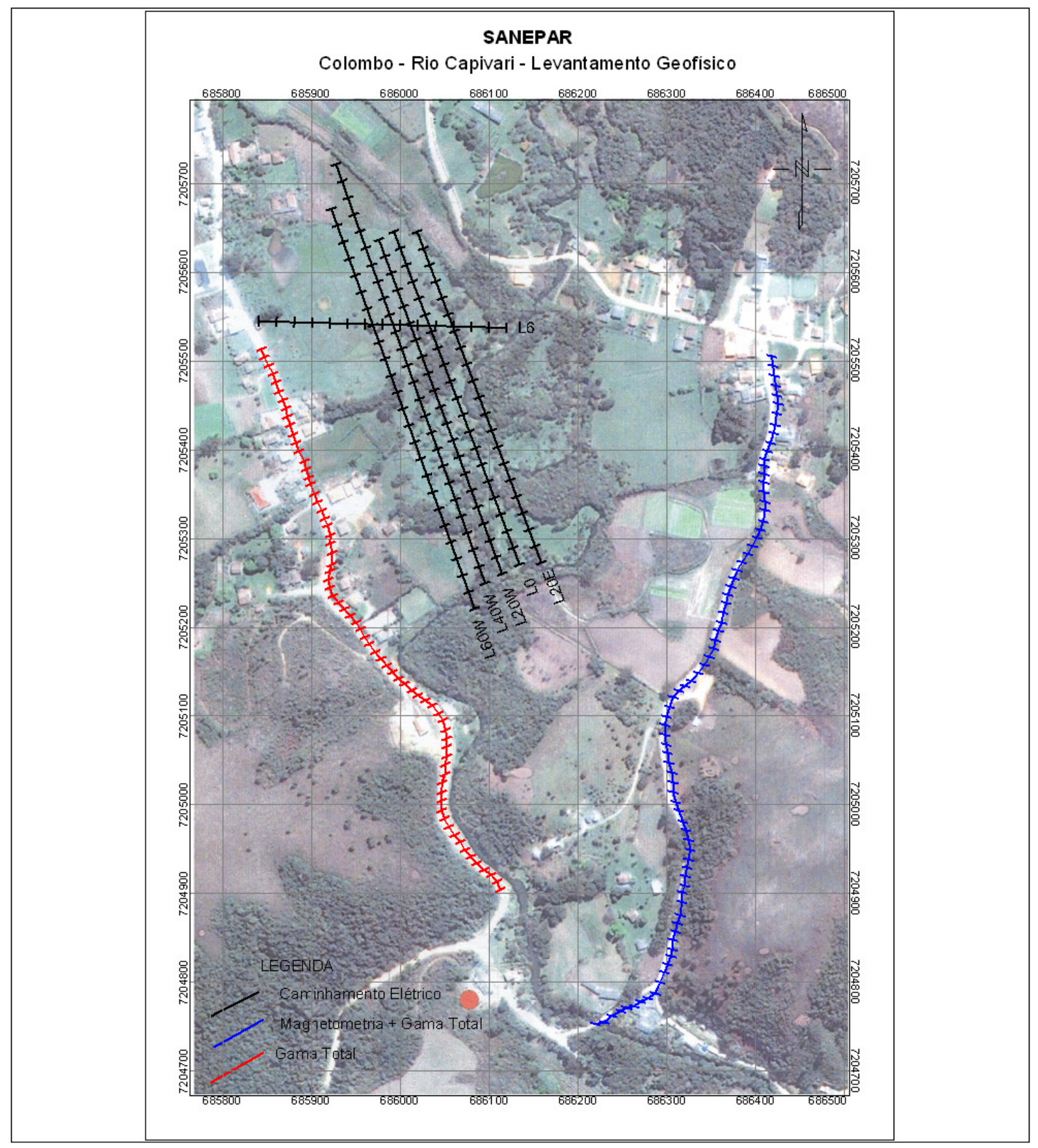

Figura 2 - Mapa de localização dos ensaios geofísicos.

Adicionalmente, dois perfis com magnetometria (campo total) e cintilometria (contagem gama total) visaram fornecer subsídios ao mapeamento geológico de um pequeno corpo granítico que ali ocorre e mapear com a magnetometria possíveis diques de rochas básicas.

Para "imagear" adequadamente a distribuição da resistividade elétrica foi selecionada a técnica de caminhamento elétrico, com arranjo de eletrodos dipolo-dipolo, com $20 \mathrm{~m}$ de espaçamento entre eletrodos e seis níveis (profundidades) de investigação. $\mathrm{O}$ espaçamento de $20 \mathrm{~m}$ visou uma resolução lateral adequada para a detecção das zonas de dissolução e dutos saturados, contemplando também a profundidade de interesse que atinge cerca de $35 \mathrm{~m}$.

Como pode ser visto no mapa de localização dos ensaios (Figura 2), procurou-se cobrir da melhor forma possível o terreno, objeto do estudo, com linhas dispostas quanto possível paralelamente à direção média do rio, espaçadas de $20 \mathrm{~m}$, gerando uma malha quadrada, muito apropriada para a detecção pretendida. 


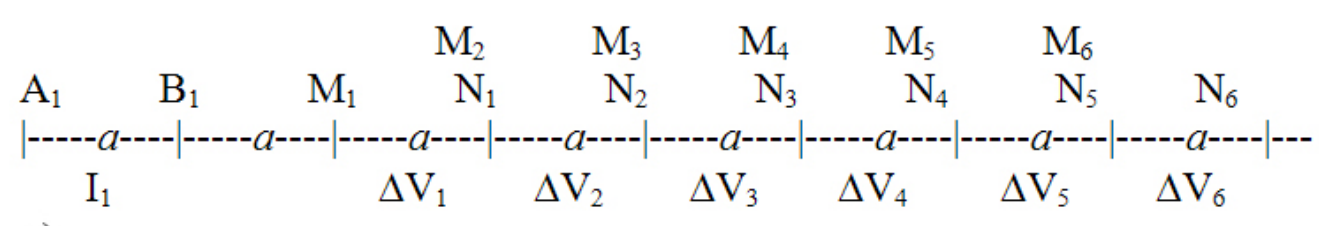

a)

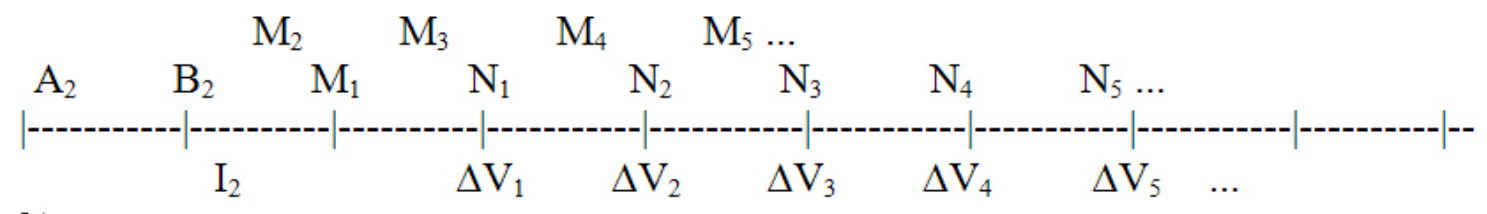

b)

Figura 3 - Arranjo eletródico dipolo-dipolo (explicação no texto).

As condições da aquisição dos dados do caminhamento elétrico foram normais, com excelente qualidade de medidas. $\mathrm{O}$ terreno foi considerado suficientemente plano para que não fosse necessário incorporar a altimetria na modelagem numérica dos dados de resistividade.

A partir do caminhamento elétrico foi detectado um lineamento condutor com as características procuradas. $\mathrm{O}$ perfil magnetométrico atesta ausência de rochas básicas no local e nas suas proximidades, enquanto a cintilometria auxiliou na delimitação de um corpo granítico que faz contato com a célula cárstica investigada.

\section{DESCRIÇÃO DAS TÉCNICAS UTILIZADAS}

\section{Caminhamento elétrico}

Na Figura 3 é mostrado o arranjo de eletrodos dipolo-dipolo que foi utilizado na técnica de caminhamento elétrico. Em (a) observa-se a posição inicial dos eletrodos de corrente para a qual são medidas diferenças de potencial $\Delta \mathrm{V}_{1}$ a $\Delta \mathrm{V}_{6}$ no caso exemplificado, em 6 pares de eletrodos de potencial afastados de $n=1$ a $n=6$ vezes " $a$ "; em (b) mostra-se a segunda posição dos eletrodos de corrente $\mathrm{AB}$ para a qual são novamente lidas as diferenças de potencial entre 6 pares de eletrodos de potencial. Assim sucessivamente até cobrir a linha de levantamento.

Com a diferença de potencial $\Delta V$ medida entre $\mathrm{M} \mathrm{e} \mathrm{N} \mathrm{e} \mathrm{a} \mathrm{corrente} I$ transmitida no par de eletrodos A e B, calculou-se a resistividade aparente pela relação:

$$
\rho_{a}=\frac{\Delta V}{I} \cdot F_{G} .
$$

Nesta expressão, $F_{G}$ é o fator geométrico, função das distâncias entre os eletrodos envolvidos no arranjo de medida.

A distância crescente $n=1$ a $n=6$ vezes " $a$ " entre $\mathrm{AB}$ e $\mathrm{MN}$ determina profundidades crescentes de investigação. Por isto utilizou-se o termo nível (profundidade) de investigação $n_{1}$ a $n_{6}$. No exemplo da Figura 3, para cada posição $\mathrm{AB}$ são medidos 6 níveis. $\mathrm{O}$ arranjo progride de um espaçamento " $a$ " cada passo de 6 medidas até cobrir a linha de levantamento. O resultado inicial é uma seção de resistividade aparente, também chamada pseudoseção (Figura 4), porque nem a resistividade é a real do ponto ao qual ela é atribuída e nem a posição espacial da medida é conhecida com exatidão.

As medidas de resistividade aparente do caminhamento elétrico com arranjo dipolo-dipolo são então inicialmente plotadas na interseção das linhas que partem do meio de $\mathrm{AB}$ e do meio do $\mathrm{MN}$, com inclinação de $45^{\circ}$ (Figura 4 ), constituindo a pseudo-seção de resistividade aparente. No exemplo da Figura 4 o caminhamento foi feito com 8 níveis de investigação e espaçamento de $10 \mathrm{~m}$ entre eletrodos. Note-se que a primeira seqüência (Seqüência 1) de medidas e a segunda (Seq.2) referentes às $1^{\mathrm{a}}$ e $2^{\mathrm{a}}$ posições de eletrodos de corrente discutidas com relação à figura 3. Os dados, depois contornados, são mostrados através de escala de cores. 


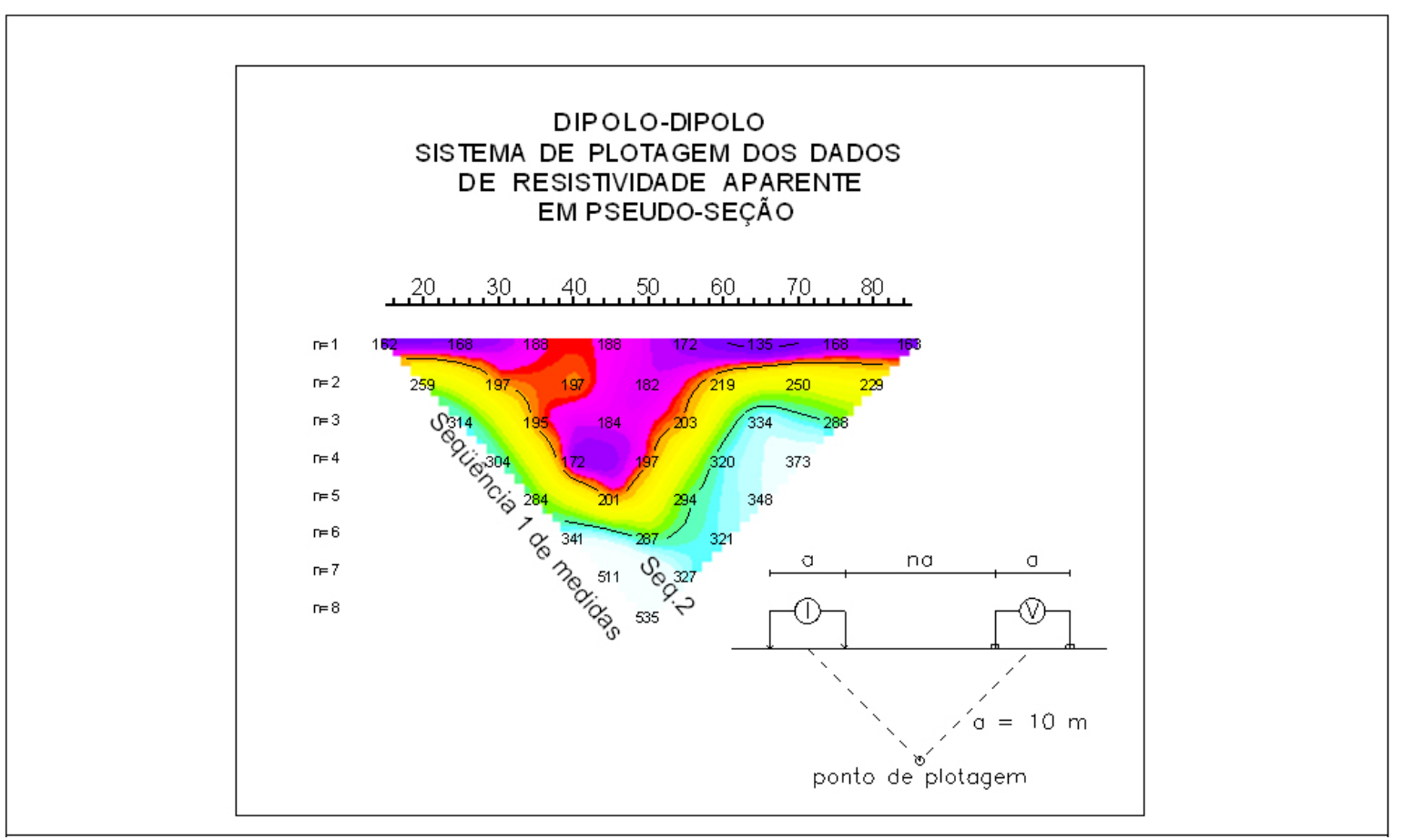

Figura 4 - Sistema de plotagem do arranjo dipolo-dipolo em pseudo-seção de resistividade aparente.

Ao asumir uma distribuição de resistividade 2D, as pseudo-seções podem ser modeladas numericamente para determinar a seção "real", ou uma seção modelo que, numericamente, produz uma seção de resistividade aparente que se compara tão bem quanto possível à observada. Este processo de modelagem é conhecido como inversão na geofísica e foi utilizado no presente estudo como é mostrado a seguir.

No caso do caminhamento elétrico, que gera pseudo-seções de resistividade, cujos efeitos de eletrodos muitas vezes são de difícil interpretação, a inversão $2 \mathrm{D}$ de resistividade, disponível apenas a partir de meados da década de 90, veio facilitar muito a interpretação. A inversão de dados geofísicos coloca à disposição do intérprete uma distribuição da propriedade física analisada, que se pode aproximar muito da real. Contudo, deve ser lembrado que o processo inverso não tem solução única e ficar alerta para as variações possíveis do modelo obtido.

$\mathrm{O}$ resistivímetro utilizado no levantamento geoelétrico, objeto deste trabgalho, foi o TDC 1000/24R2A de fabricação Tectrol. O transmissor de corrente possui 1000 Watts de potência, o que assegurou a corrente necessária para que as diferenças de potencial fossem lidas com a precisão requerida.

Magnetometria

A medida da intensidade magnética total foi feita com um magnetômetro de precessão de prótons com efeito overhauser, modelo GSM19 de fabricação GEM Systems. Como mostra a Figura 5, o campo total $\mathrm{B}$ medido é a soma do campo magnético da terra $\mathrm{B}_{0}$ e do campo anômalo $\mathrm{B}_{\mathrm{A}}$. Sabe-se que os corpos de rochas básicas que ocorrem na forma de diques na região de estudo fornecem intensas anomalias magnéticas com forma semelhante à mostrada no canto inferior esquerdo desta figura.

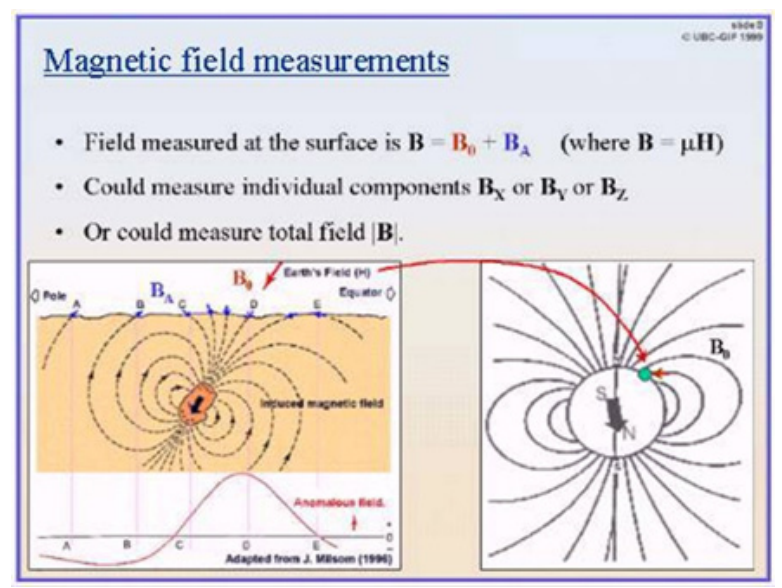

Figura 5 - Princípio da magnetometria. Figura extraida do site UBC-GIF da Universidade de British Columbia.

Como ilustrado na Figura 5, o campo magnético da terra $\mathrm{B}_{0}$ (canto inferior direito), que pode ser desmembrado em componentes $B_{x}$, $\mathrm{B}_{\mathrm{y}}$ e $\mathrm{B}_{\mathrm{z}}$, que por sua vez poderiam ser medidas individualmente, provoca uma magnetização $B_{A}$ nos corpos magnéticos (canto inferior esquerdo). 
As medidas de $\mathrm{B}$ total $\left(\mathrm{B}_{0}+\mathrm{B}_{\mathrm{A}}\right)$ possibilita a detecção dos corpos magnéticos pela anomalia criada pelos mesmos (perfil no canto inferior esquerdo). A unidade do campo magnético total utilizada na geofísica é o nanoTesla (nT) que equivale a $10^{-9}$ Teslas.

Apenas um perfil magnetométrico foi feito na área (ver Fig.2). Sua posição é adequada para detectar os diques de diabásio com orientação NW que, supsotamente, estariam cortando a área de estudo. Para possibilitar a detecção, incluindo os diques menores descontínuos, o espaçamento entre pontos de medida foi de $10 \mathrm{~m}$.

Quando foi medido campo magnético total, incorporou-se na medida o efeito de campos magnéticos com origem externa à terra. Este efeito pode ser de algumas dezenas de nanoTeslas. Dependendo da resolução requerida, os campos de origem externa precisam ser monitorados ao longo do levantamento, para a variação diurna para a correção dos dados. O controle da variação diurna foi feito com o mesmo magnetômetro do levantamento, com retorno a uma estação base.

\section{Cintilomentria}

Elementos radioativos naturais como isótopos do Potássio, Urânio e Tório emitem radiação gama que pode ser detectada em sensores de aparelhos ditos cintilômetros quando a contagem é total, sem distinção entre diferentes energias de radiação. No caso da medida descriminar diferentes energias da radiação, podendo determinar se a radiação provém do Potássio, do Urânio ou do Tório, diz-se que o instrumento de medida é um gama-espectrômetro. A cintilometria e a gamaespectrometria são geralmente agrupadas como métodos radiométricos ou de radiometria. No presente estudo utilizou-se um cintilômetro, modelo GR101A de fabricação Geometrics, para um rápido reconhecimento, visando delimitar a extensão de um corpo granítico. A medida radiométrica é geralmente fornecida em contagens por segundo.

Para as rochas que ocorrem na região do estudo, as graníticas seriam as mais responsivas em termos de radiação gama, enquanto as rochas básicas seriam as menos responsivas. As rochas calcárias também apresentam muito baixa contagem. Metassedimentos finos como os filitos apresentam contagem superior à das rochas calcárias, mas inferior à dos granitos.

Os dois perfis de medida gama total foram feitos com espaçamento de $10 \mathrm{~m}$ entre pontos, ao longo de estradas de chão como pode ser visto na Figura 2.

\section{BASE DE DADOS}

\section{Caminhamento elétrico}

A Figura 6 mostra com mais detalhe a malha de caminhamento elétrico, com indicação inclusive de feições cársticas (dolinas) que acompanham o eixo condutor detectado.

Os dados de resistividade aparente do arranjo dipolo-dipolo foram inicialmente plotados em pseudo-seções. Elas constituem a base de dados dos ensaios geoelétricos e podem ser vistas nas figuras 6 e 7. Servem como controle de qualidade dos dados, bem como permitem uma avaliação qualitativa da variação de resistividade detectada.

Nas pseudo-seções empilhadas (Fig.7) observam-se efeitos de eletrodos que revelam feições de resistividade baixa (tons vermelhovioleta) associáveis ao carste saturado. Contudo, as profundidades das quais provêm os efeitos de eletrodos não são evidentes na análise visual das pseudo-seções. Por vezes os dois efeitos de eletrodos (de corrente e de potencial) são bem visíveis, em outras, como na parte do lado direito das linhas (porção NW), um dos eixos da anomalia tipo pernas de calça (o da esquerda) não é tão intenso como o outro (o da direita). Mas podese ver claramente que ocorrem anomalias com baixa resistividade que se alinham em direção ao rio Capivari cujas curvas são cortadas pela linha L20E. Configuram-se, assim, possíveis dutos nas rochas calcárias que podem ter conexão com o rio.

Tendo em vista o alinhamento que adiante será tratado como "condutor principal" e o alinhamento de dolinas observado pela equipe geofísica no campo (ver Fig. 3), decidiu-se por levantar a linha transversal L6 ao longo deste lineamento. Pode-se ver na pseudo-seção da L6, na Figura 7, que sua maior parte de fato corresponde a zona cárstica saturada, desenhando com muita clareza a feição de baixa resistividade como se fosse um nível ou camada. Note-se que os dados ainda não haviam sido processados quando se determinou o traçado desta linha no campo. 


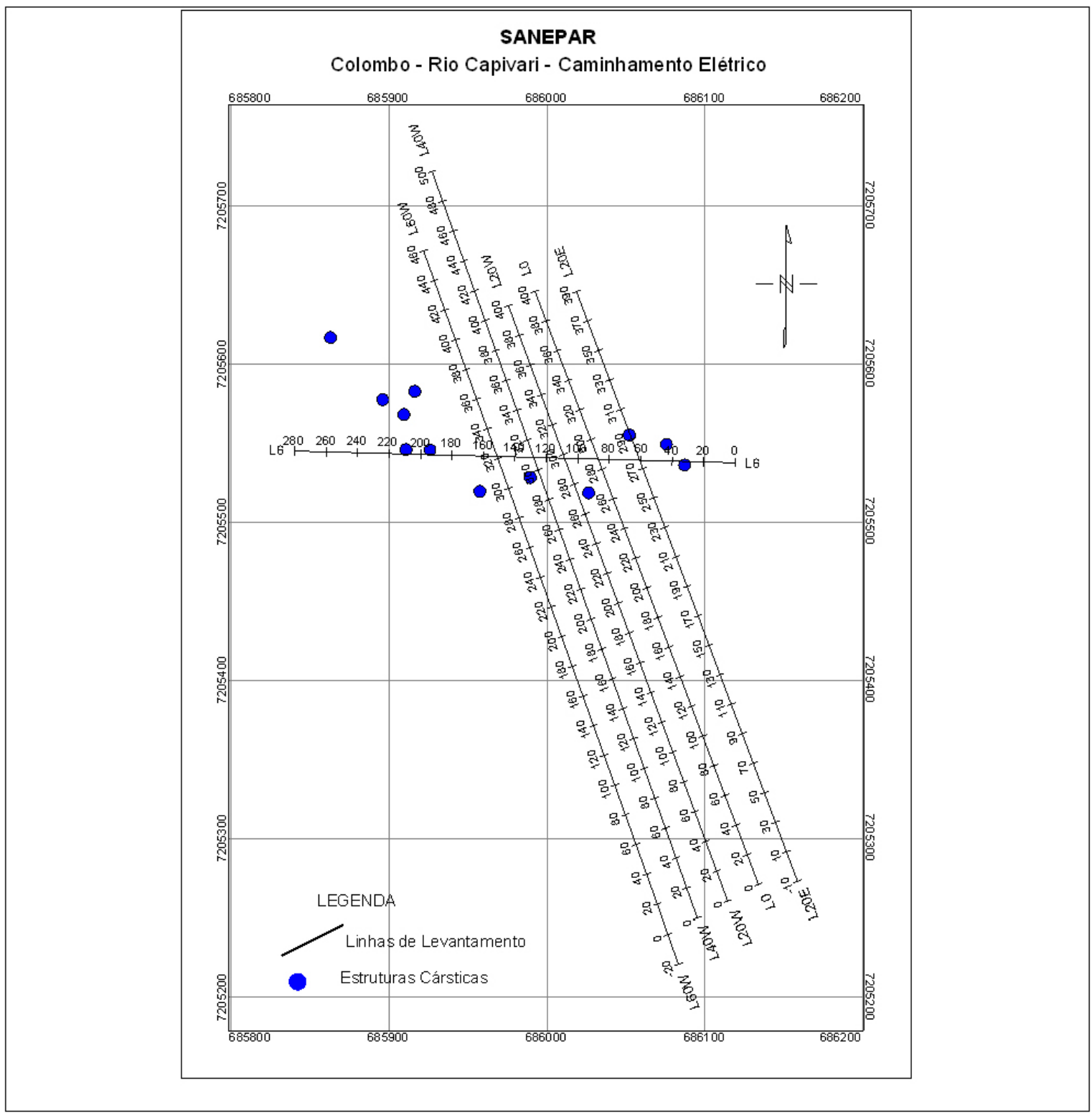

Figura 6: Localização detalhada das linhas de caminhamento elétrico e posições de dolinas observadas pela equipe geofísica no campo.

Perfis levantados com magnetometria e cintilometria

Abase de dados é composta também pelos perfis magnetométrico e radiométricos (cintilométricos ou de contagem gama total) com podem ser vistos na Figura 2.

A densa malha de energia elétrica na área dificulta muito a magnetometria. Embora esteja sendo apresentado apenas um perfil magnetométrico, várias outras tentativas de levantamento foram frustradas pelo intenso ruído da rede de energia. Além deste problema, em boa parte da área contígua à de interesse ao estudo, existem plantações delicadas de hortaliças, nas quais os proprietários opuseramse terminantemente a que se tivesse acesso. Os dois perfis levantados com a contagem gama total acompanharam estradas de chão, mas tomou-se o cuidado de posicionar o cintilômetro nas bordas para minimizar o efeito de possíveis materiais alóctones por ventura utilizados no lastro e compactação das mesmas. 


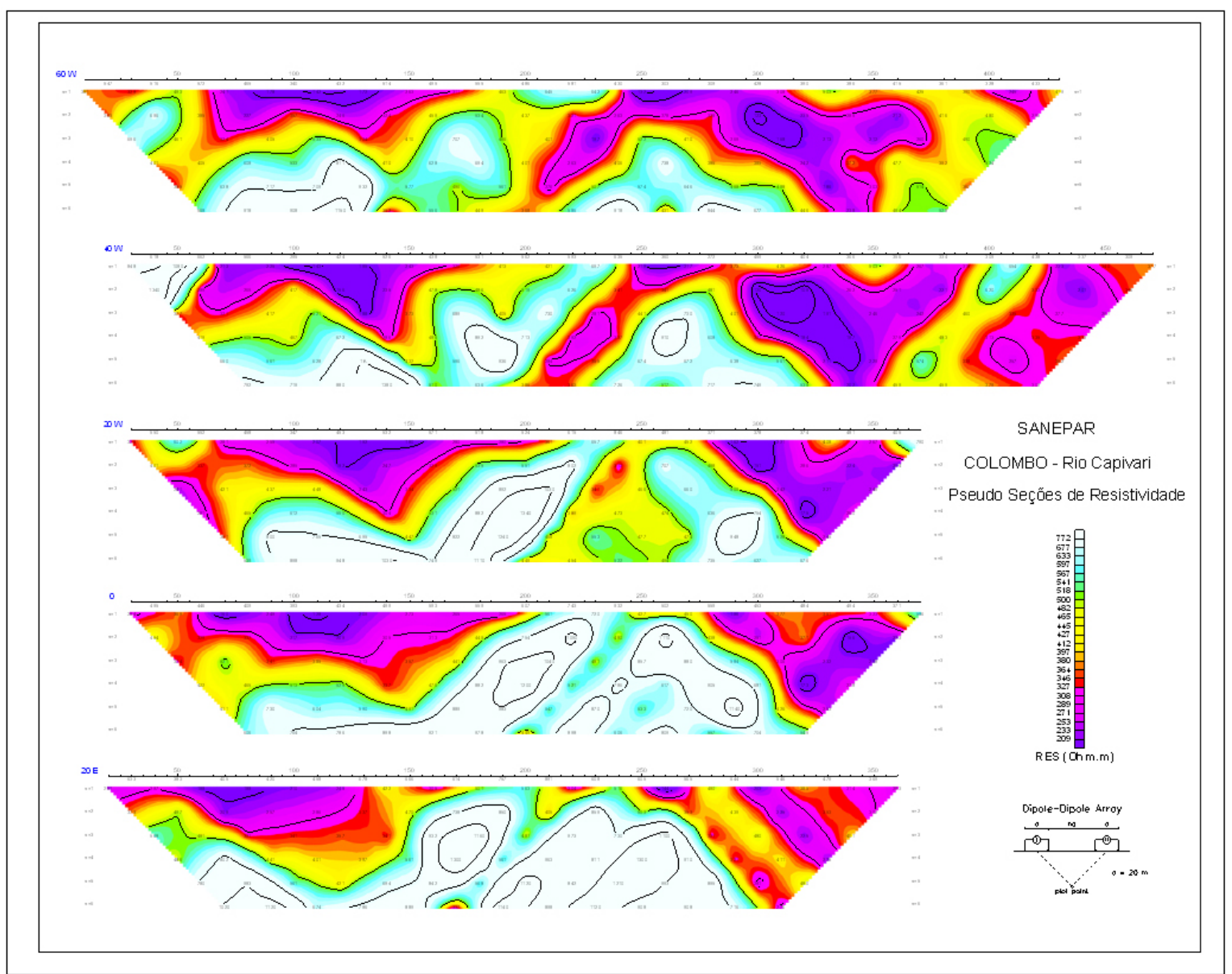

Figura 7: Pseudo-seções da malha principal. Vista de NE para SW (da linha 20E na base para a 60W no topo)

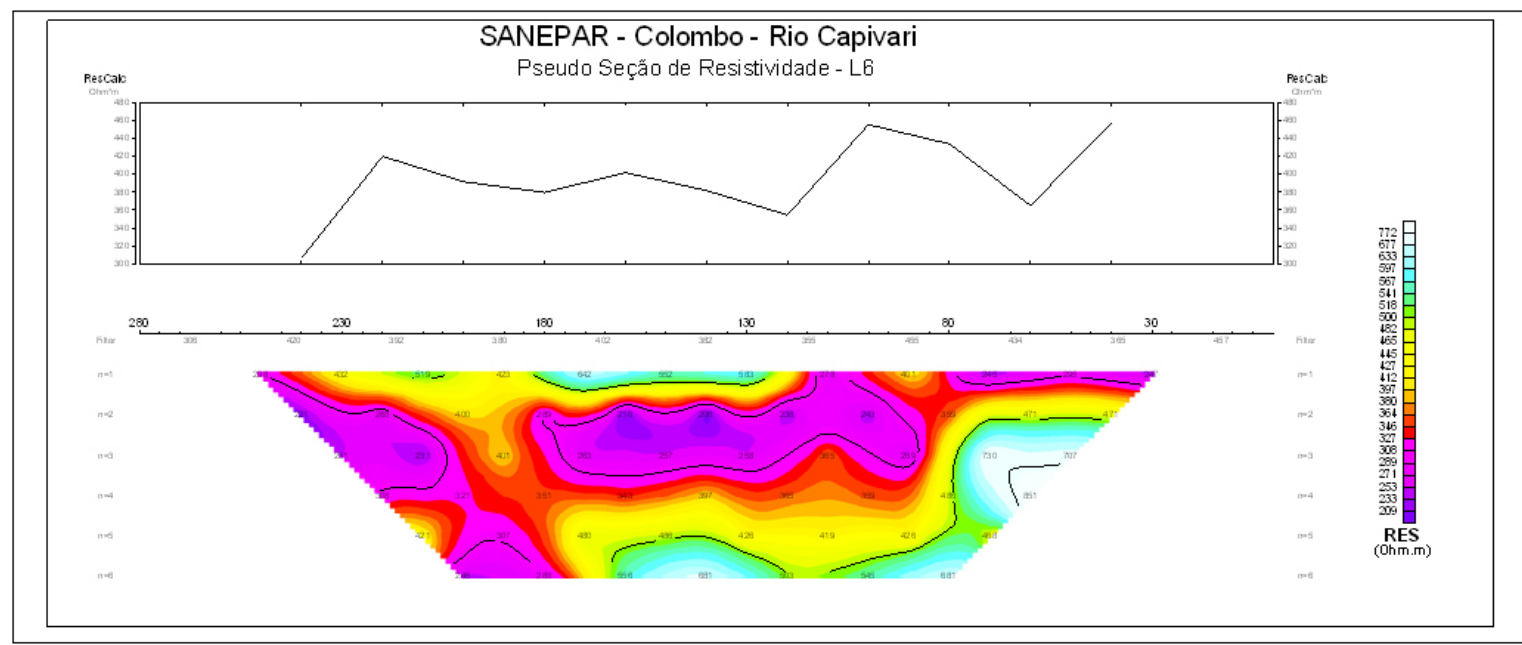

Figura 8 - Pseudo-seção da linha L6 transversal, acompanhando aproximadamente o condutor principal.

*Observação: A faixa condutora que se observa ao longo dos níveis n2 e n3, como se fosse uma camada, localmente chegando à superfície, é a resposta da zona cárstica saturada observada na malha principal. $\mathrm{O}$ perfil no topo da figura refere-se à resistividade média calculada a partir da pseudo-seção, com um filtro Fraser na forma de "pernas de calça". 


\section{A MODELAGEM NÚMERICA DA RESISTIVIDADE E SUA INTERPRETAÇÃO}

A modelagem numérica dos dados do caminhamento elétrico consistiu da inversão 2D dos dados de resistividade aparente. Por inversão entende-se o processo computacional semiautomático que, a partir de um modelo inicial, busca iterativamente o modelo de distribuição de resistividade que fornece a pseudo-seção de resistividade aparente que melhor se ajusta à observada. Assume-se então que o modelo que fornece o melhor ajuste represente a situação geoelétrica mais próxima do real possível, como deduzida a partir da teoria físico-matemática disponível. 2D significa duas dimensões ou modelo bidimensional, uma vez que se assume que o modelo de distribuição de resistividade utilizado na inversão tem dimensões infinitas na direção perpendicular à linha ensaiada. Os modelos obtidos com a inversão $2 \mathrm{D}$ são apresentados em mapas de diferentes profundidades, constituindo um modelo pseudo-3D. É dito "pseudo" porque é obtido a partir de levantamento 2D.

A figura 9 ilustra o resultado da inversão 2D. No topo da figura tem-se a pseudo-seção observada, sendo que na base o modelo de distribuição "real" de resistividade produz numericamente a pseudo-seção do meio, que "se parece" tão bem quanto possível com a observada. "Parecer-se" aqui é medido pelos parâmetros RMS e Norma L2, mostrados na base dos quadros de seções. Quanto menores estes valores, melhor é o ajuste, dentro do critério de mínimos quadrados. Em primeira aproximação, o ajuste pode ser julgado visualmente pela semelhança entre as pseudoseções calculada e observada. O software que faz a inversão dos dados não tem a preocupação de refinar a apresentação de resultados. Por isto, os modelos obtidos foram replotados em software mais apropriado para representação gráfica.

As figuras 10, 11 e 12 mostram as seções modelo e seções modelo interpretadas Mesmo no tamanho normal A4, é possível identificar a zona condutora (vermelho-violeta/roxo) que ocorre na parte direita (parte NW) das seções justapostas. O alinhamento destas feições de baixa resistividade foi denominado de condutor principal. Ele constitui uma alternativa de zona cárstica (dutos) que se constitui em aqüífero com possível conexão com o rio Capivari, como a feição procurada. A zona condutora que ocorre na parte esquerda (parte SE), que às vezes se aprofunda, como assinalado nas seções interpretadas, também pode se constituir em alternativa para o aproveitamento do objeto pesquisado. Contudo, não é seguro que o alinhamento destas zonas condutoras seja produzido por estruturas cársticas. Pode simplesmente tratar-se de falhamento ou contato litológico falhado.

Reforça a indicação da primeira alternativa (condutor principal) a distribuição da resistividade observada na linha L6, que se estende na proximidade do alinhamento do condutor principal. Observa-se nesta linha (ver Fig. 12) que um nível condutor conecta a borda do rio no extremo Leste da linha ao outro extremo próximo da estrada no lado W. A imagem que se observa desenhada em tons vermelho-violeta é a expressão do que se estava buscando com a investigação geofísica: uma zona cárstica que pode constituir aqüífero com possível conexão com o rio. Para uma visualização $3 \mathrm{D}$, amostram-se os valores de cada seção modelo ("seção real") em determinadas profundidades e fez-se o contorno destes valores em mapas. Os mapas das profundidades $5,15,27$ e $40 \mathrm{~m}$ são mostrados nas Figuras 13 a 16. Na profundidade de 5m (Fig. 13) desenha-se um eixo condutor bem definido que se conecta ao rio Capivari no extremo NE da linha L6. Nesta profundidade a zona condutora associada ao condutor principal está mais a sul. Na profundidade de $15 \mathrm{~m}$ (Fig. 14) nota-se um deslocamento para Norte do condutor principal. Por outro lado a zona condutora mais a sul conecta-se ao rio e cruza toda a malha. $\mathrm{Na}$ profundidade de $27 \mathrm{~m}$ (Fig. 15) o condutor principal aparece como uma zona condutora bem maior e é interrompido por falta de amostragem do arranjo dipolo-dipolo nesta profundidade no extremo norte das linhas. A zona condutora do sul da área perde continuidade. Situação em tudo semelhante a esta é observada na profundidade de $40 \mathrm{~m}$. Chama-se atenção, contudo, para o fato que a sensibilidade do arranjo utilizado diminui a partir de $34 \mathrm{~m}$ de profundidade.

Fecha-se assim a discussão sobre os resultados do levantamento com caminhamento elétrico, salientando-se uma faixa de baixa resistividade detectada na parte norte da área de estudo. Ela foi chamada de condutor principal e parece atender em todos os aspectos à demanda do projeto que busca o aqüífero carste, com possível conexão com o rio Capivari. 


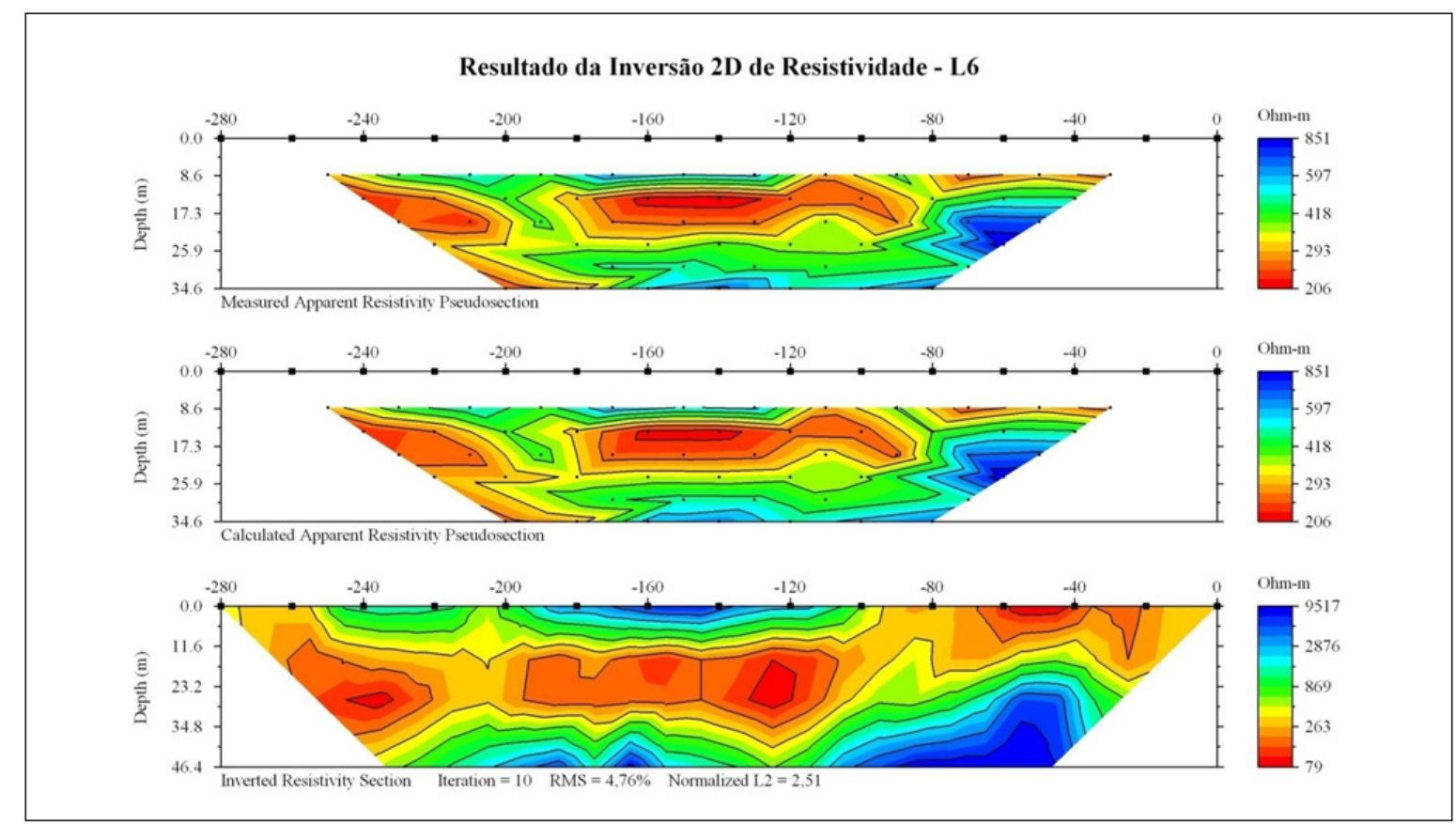

Figura 9 - Exemplo de resultado da inversão 2D de resistividade - Linha L6 (demais resultados no Anexo I): pseudo-seção observada (no topo); seção modelo (na base), que reproduz numericamente a pseudoseção calculada (seção do meio) que apresenta o melhor ajuste com a observada. O ajuste pode ser apreciado visualmente e pelo valor RMS e Norma L2.

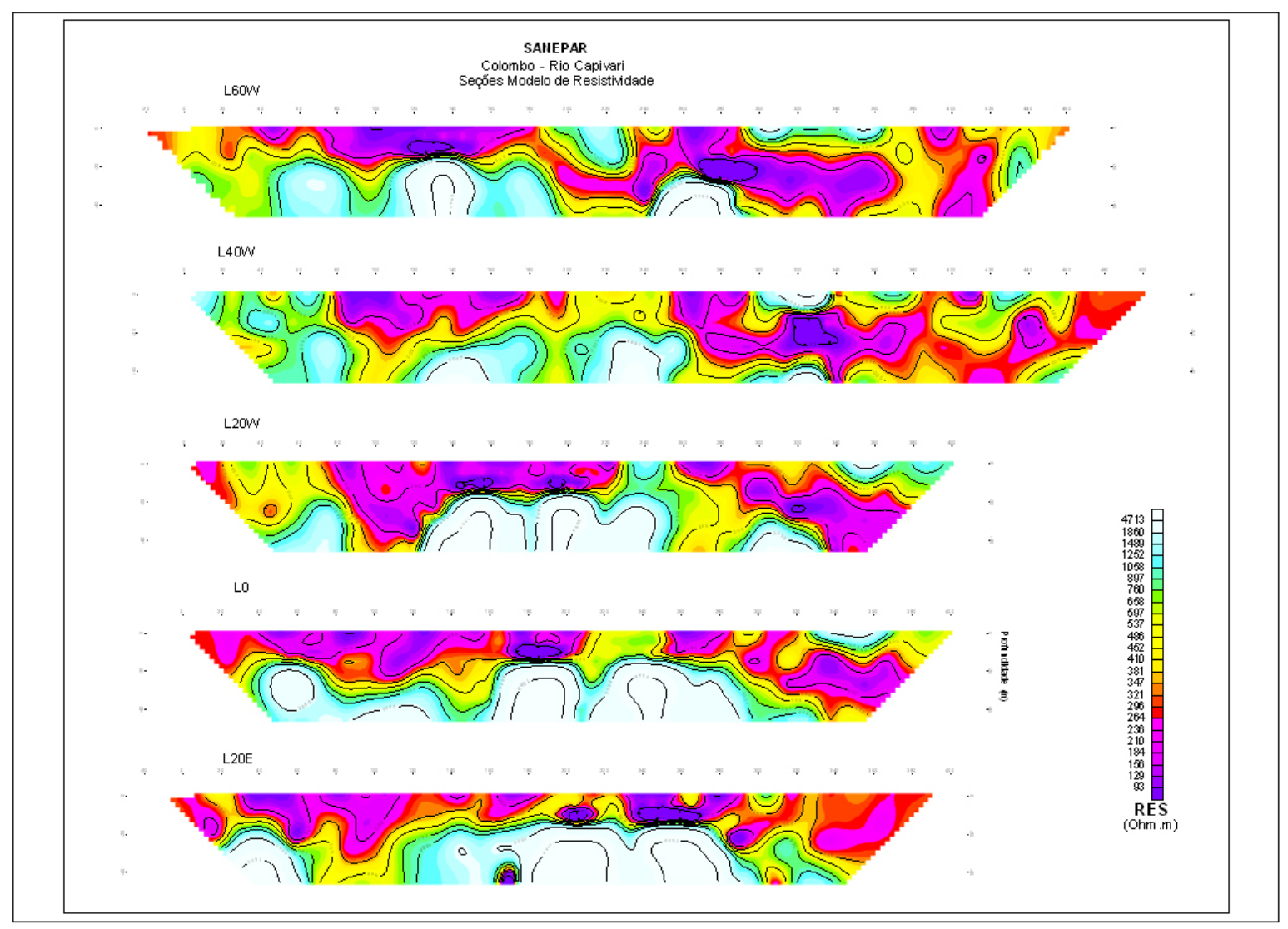

Figura 10 - Malha principal - Seções modelo de resistividade. 
Prospecção de estruturas subterrâneas para processos de recarga indireta do Aqüífero Cárstico com águas do Rio Capivari, Colombo, PR

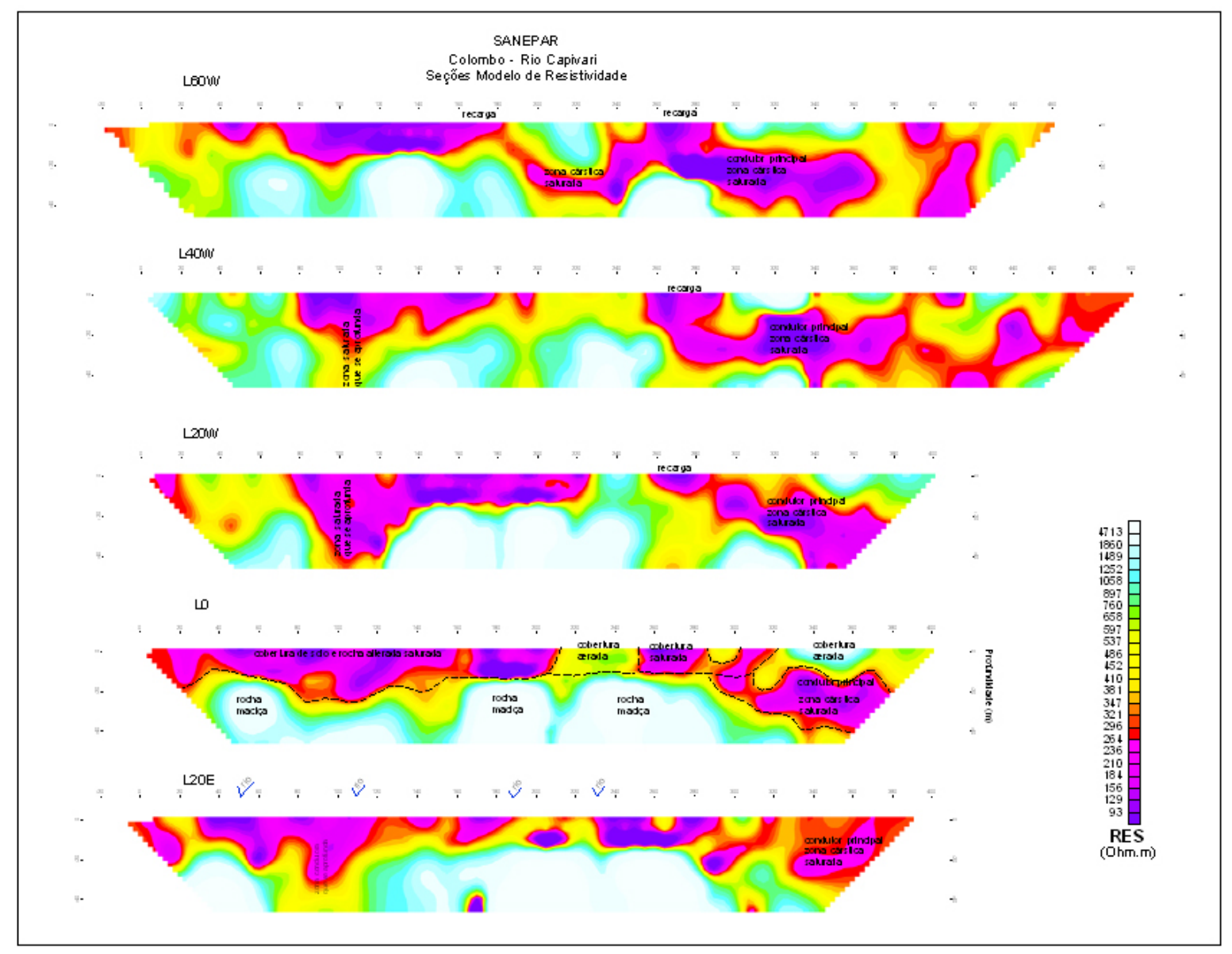

Figura 11: Malha principal - Seções modelo interpretadas.

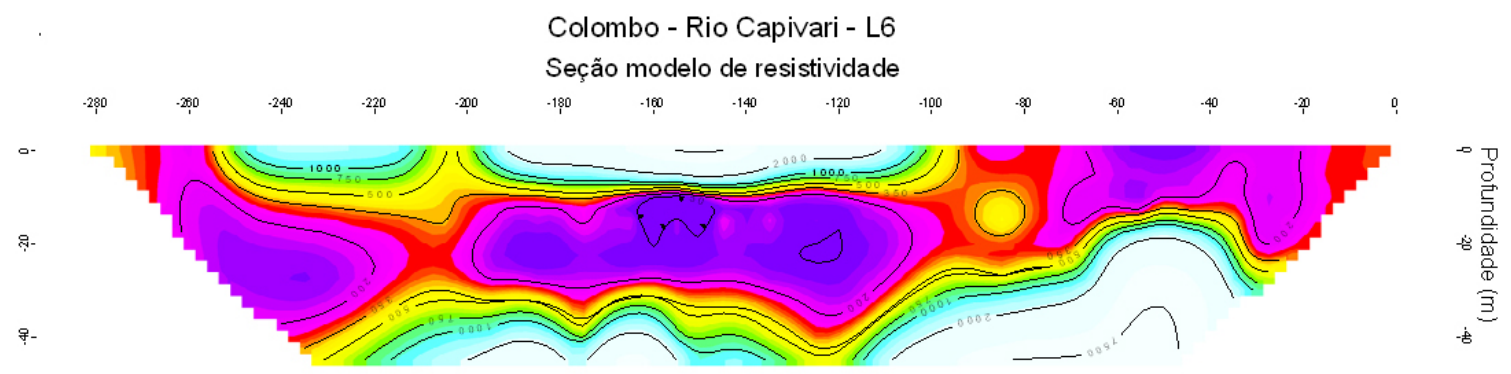

Colombo - Rio Capivari - L6

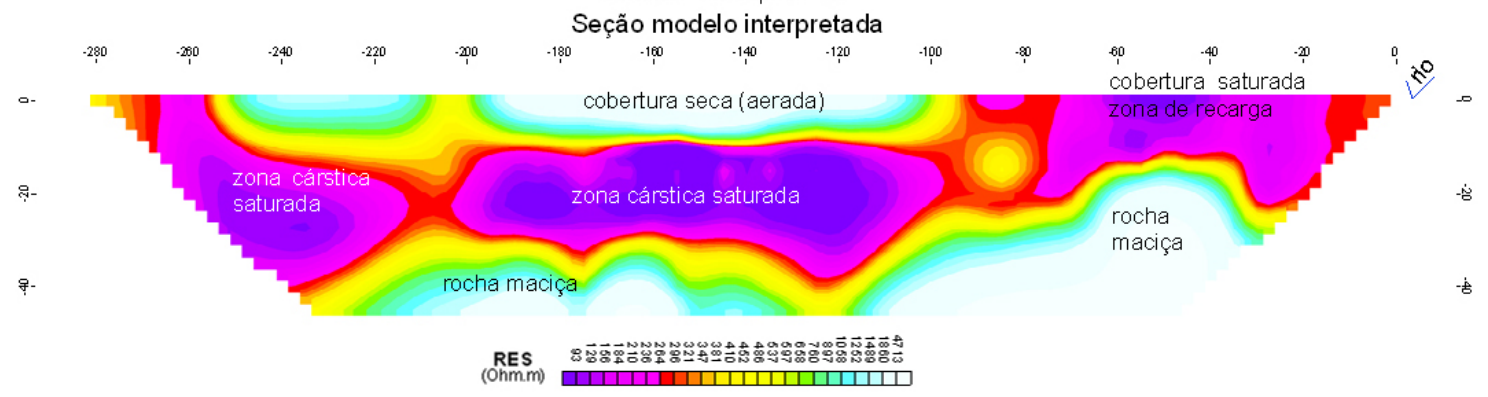

Figura 12: Linha L6 - Seção modelo (topo) e seção modelo interpretada (base). 


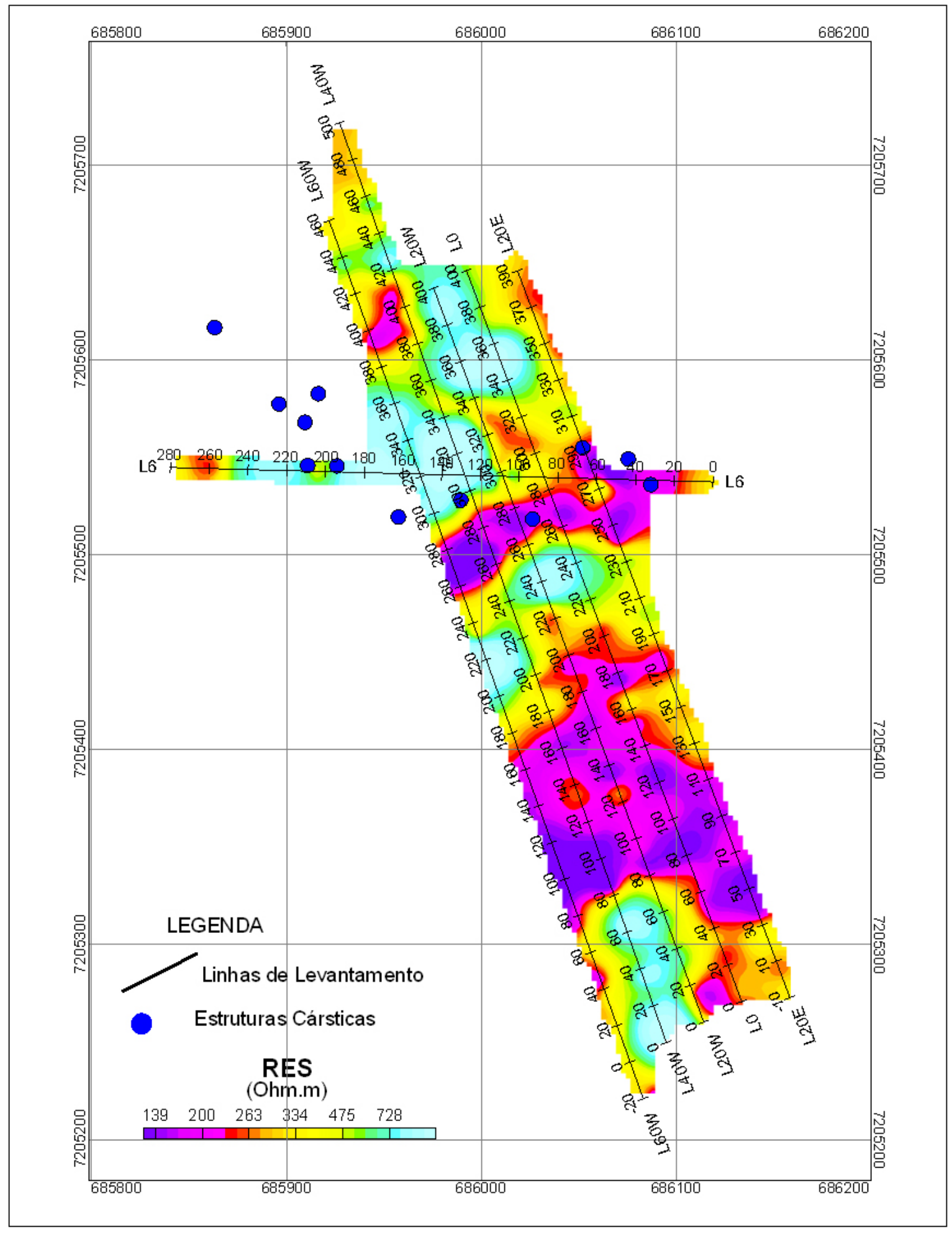

Figura 13: Mapa da resistividade na profundidade de $5 \mathrm{~m}$.

*Observação: Nesta profundidade desenha-se um eixo condutor bem definido que se conecta ao rio Capivari no extremo NE da linha L6. 
Prospecção de estruturas subterrâneas para processos de recarga indireta do Aqüífero Cárstico com águas do Rio Capivari, Colombo, PR

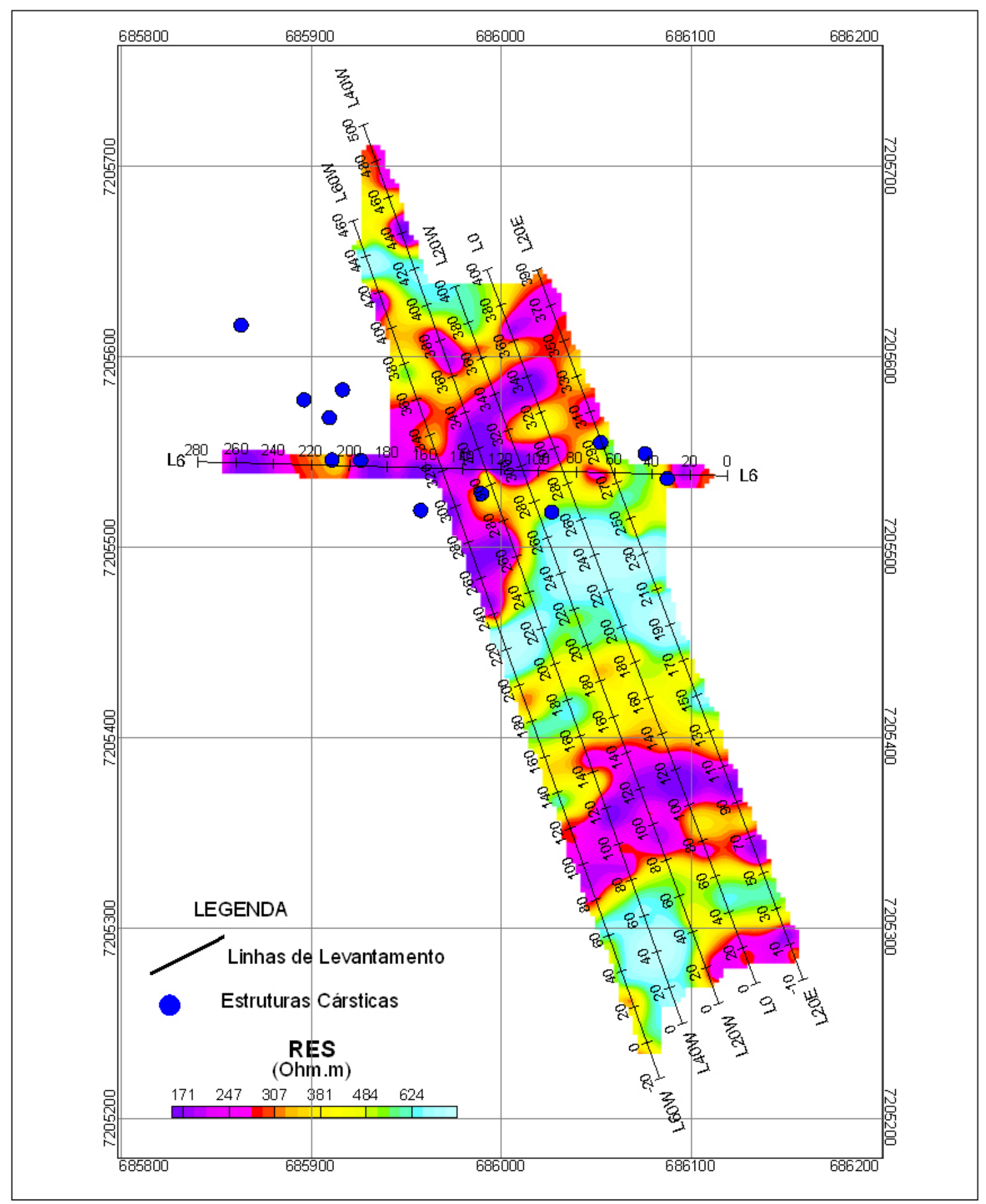

Figura 14 - Mapa da resistividade na profundidade de $15 \mathrm{~m}$. Nota-se um deslocamento para Norte do condutor principal. Por outro lado a zona condutora mais a sul conecta-se ao rio e cruza toda a malha principal. 


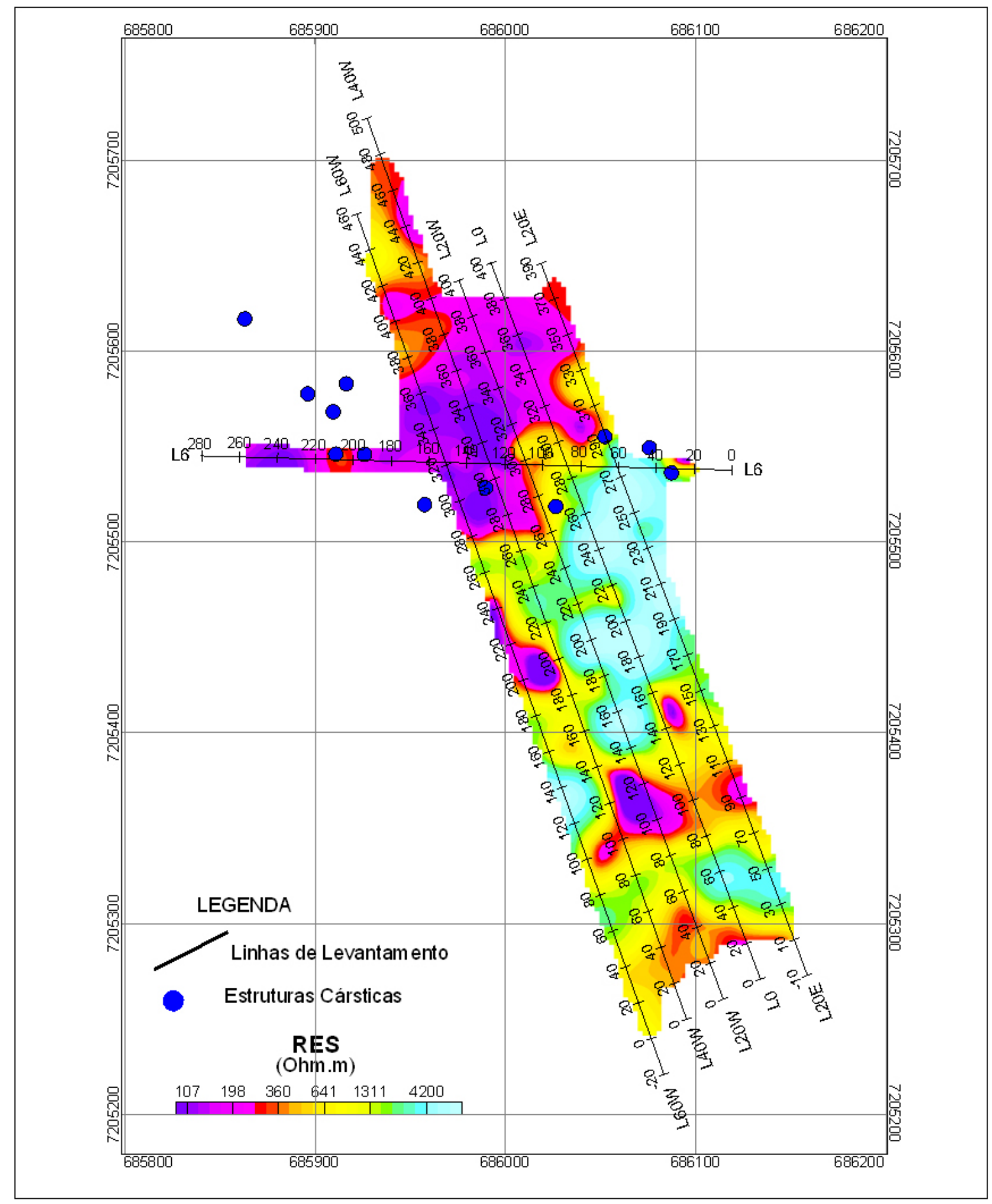

Figura 15 - Mapa da resistividade na profundidade de $27 \mathrm{~m}$.

O condutor principal aparece como uma zona condutora bem maior e é interrompido por falta de amostragem do arranjo dipolo-dipolo nesta profundidade no extremo norte das linhas. A zona condutora do sul da área perde continuidade. 
Prospecção de estruturas subterrâneas para processos de recarga indireta do Aqüífero Cárstico com águas do Rio Capivari, Colombo, PR

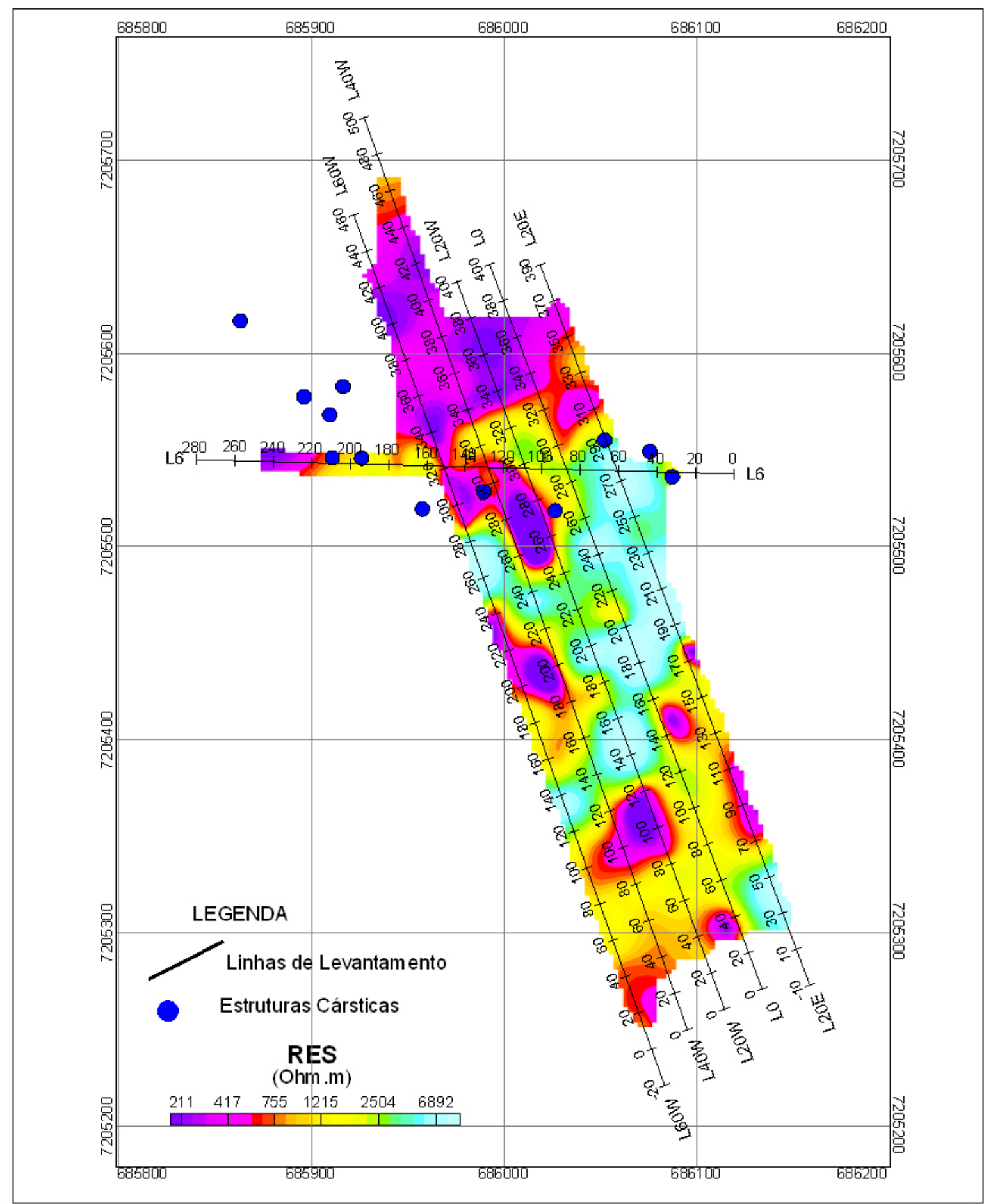

Figura 16 - Mapa da resistividade na profundidade de 40m. O condutor principal na parte norte é semelhante ao observado na Figura 15, mas deve-se ter em mente que o arranjo utilizado tem sua sensibilidade diminuida a partir de $34 \mathrm{~m}$ de profundidade. 


\section{RESULTADOS DA MAGNETOMETRIA E CINTILOMETRIA}

$\mathrm{Na}$ Figura 17 o perfil magnetométrico é desenhado com o nível de referência no valor de $22900 \mathrm{nT}$ acompa-nhando o traçado da estrada. Os valores acima desta referência são plotados com sombreado mais escuro e os abaixo, com sombreado mais claro. A escala vertical do perfil é de $200 \mathrm{nT}$ por $\mathrm{cm}$, mas deve-se considerar uma certa distorção na passagem da figura para o texto.

$O$ perfil tem sua parte central bem suave, sem variação magnética que possa ser atribuída a litologia magné-tica. Este segmento não cobre o intervalo total necessário para certificação de que não ocorre dique de rocha básica cortando a área de interesse. Contudo, apesar de o extremo norte do perfil ser muito afetado por ruído da rede de energia elétrica, não apre-senta a menor tendência à resposta de dique. A experiência mostra que, nesta região, mesmo na presença de rede elétrica em zona urbana, os diques de rocha básica são detectados pela magnetometria, apenas tem sua caracterização prejudi-cada.

No extremo sul do perfil também se observa intenso ruído provocado pela rede de energia.

Conclui-se que o perfil magnetométrico não detectou variações litológicas.

Os perfis de cintilometria são exibidos na Figura 18. O nível de referência tem o valor de 0,8 contagens por segundo que foi o valor médio medido. A escala vertical é de uma contagem por $\mathrm{cm}$. Os valores acima de 0,8 foram plotados com o tom de cinza mais escuro e os abaixo com tom mais claro. A variação total foi de 0,5 a 3 contagens por segundo. $\mathrm{O}$ pequeno cristal do cintilômetro utilizado e seu pequeno tempo de integração justificam em parte a baixa contagem, mas sobre os calcários não se espera mesmo contagem maior. Apesar da pequena variação, observamse no Perfil 1 mudanças no nível da contagem que devem refletir variação litológica. A porção dos perfis com contagem maior deve associar-se à rocha granítica cujo afloramento é indicado na figura a seguir.

\section{CONCLUSÕES DE RECOMENDAÇÕES}

Ensaios geofísicos com métodos geoelétricos, magnetometria e cintilometria, foram executados em local de estudo hidrogeológico para caracterização de aqüífero cárstico, no município de Colombo, estado do Paraná. A resposta geoelétrica do carste saturado mostrou-se característica, com queda da resistividade elétrica facilmente detectável. Caminhamento elétrico com arranjo dipolo-dipolo objetivou o mapeamento de dutos de dissolução que pudessem não só constituir aqüífero, mas que tivessem conectividade com o rio Capivari que meandra pela área de estudo. Uma estrutura com estas características foi detectada e caracterizada, tendo sido chamada de condutor principal. Adicionalmente, um perfil levantado com magnetometria (campo total) atesta que não ocorre dique de rocha básica cortando a área de interesse ou em sua vizinhança imediata. Perfis de cintilometria (contagem gama total), apesar de apresentarem pequena variação na contagem gama, indicaram possíveis contatos da rocha granítica que ali ocorre, com os calcários que constituem o alvo do estudo.

Uma linha transversal à malha principal (linha L6), foi posicionada para, tentativamente, acompanhar o condutor principal. Seu traçado foi decidido antes do processamento final dos dados, apenas com a idéia preliminar obtida das leituras. Esta linha veio reforçar a indicação do condutor principal como excelente alternativa para o aqüífero prospectado.

Para possibilitar a visualização $3 \mathrm{D}$, os valores de cada seção modelo ("seção real") em determinadas profundidades foram plotados em mapas. Na profundidade de $5 \mathrm{~m}$ desenha-se um eixo condutor bem definido que se conecta ao rio Capivari no extremo NE da linha L6 e a zona condutora associada ao condutor principal está mais a sul. Na profundidade de $15 \mathrm{~m}$ o condutor principal mostra um deslocamento para Norte e aparece também na parte sul da área uma zona condutora com continuidade através de toda a malha e com conexão com o rio Capivari. A 27 $\mathrm{m}$ de profundidade o condutor principal tem sua área ampliada enquanto a zona condutora do sul da área perde continuidade.

A situação de aqüífero cárstico com aparente conexão com o rio Capivari na área de estudo foi então detectada pelos ensaios geoelétricos. 
Prospecção de estruturas subterrâneas para processos de recarga indireta do Aqüífero Cárstico com águas do Rio Capivari, Colombo, PR

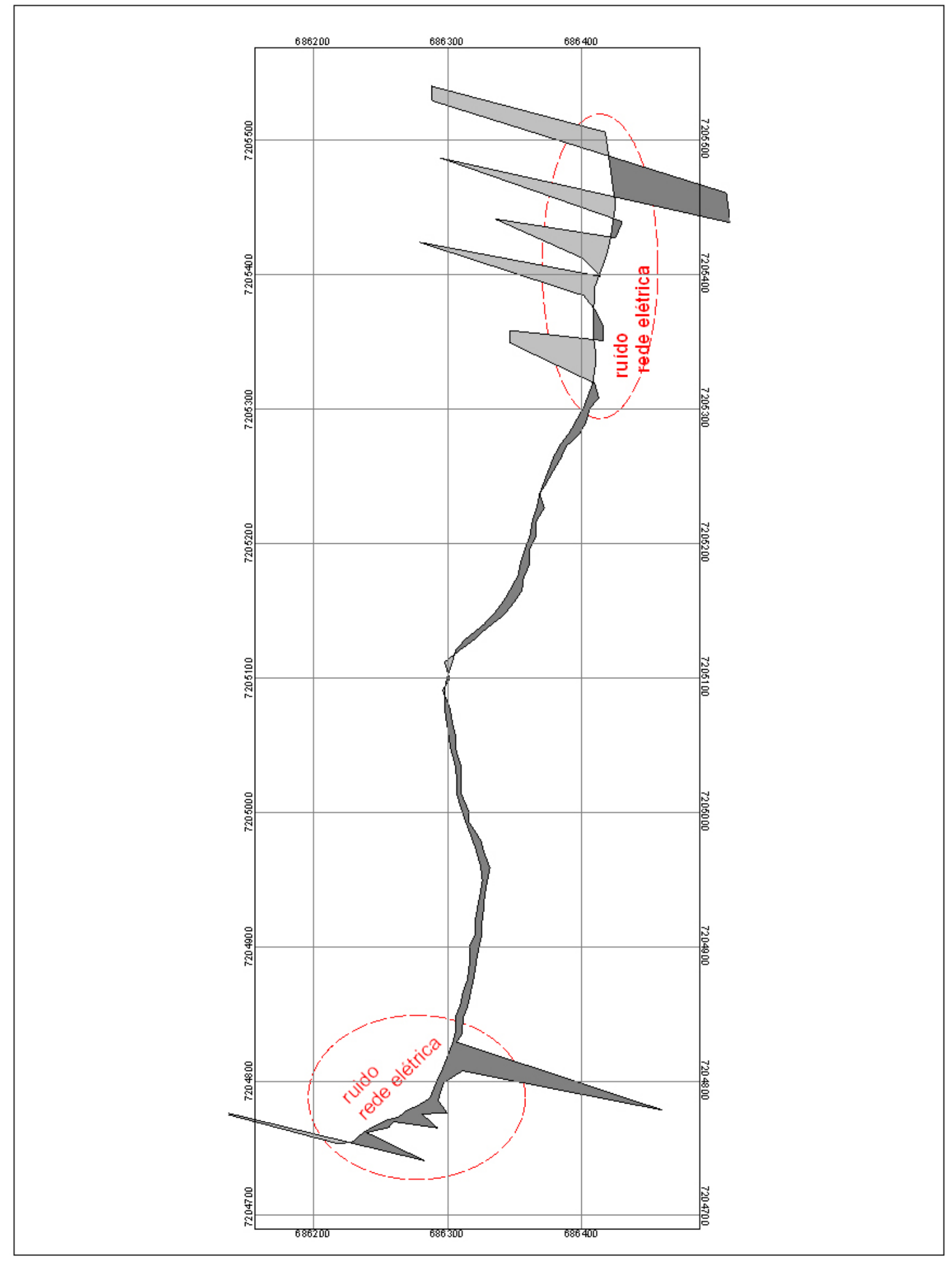

Figura 17 - Perfil magnetométrico. 


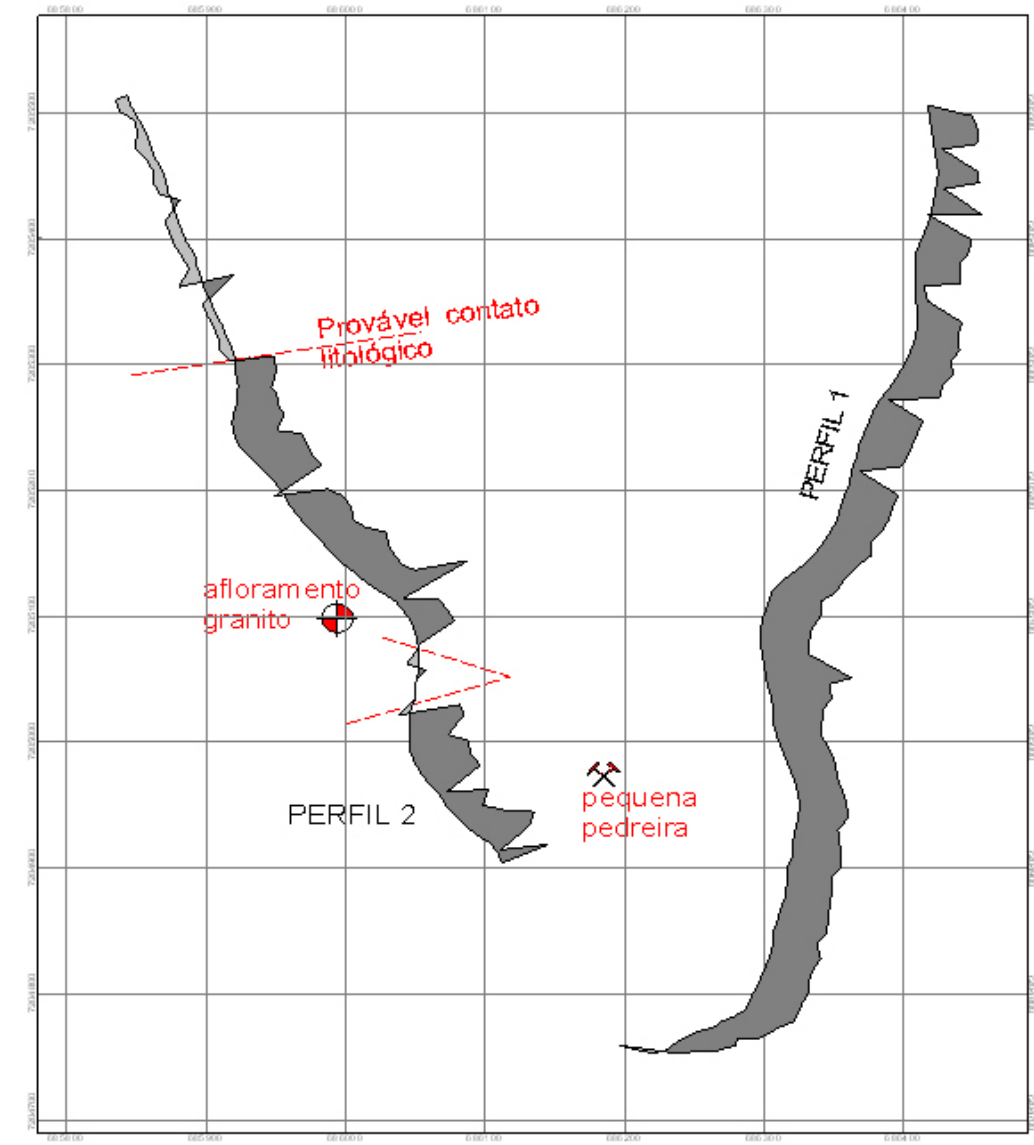

Figura 18 - Perfis de cintilometria (radiação gama total).

\section{O CLIMA E A BACIA HIDROGRÁFICA DO CAPIVARI}

O clima predominante na área de estudo, subtropical úmido, é uma das variáveis determinantes da disponibilidade hídrica do sistema cárstico. As oscilações climáticas sazonais interferem, por curtos períodos, nas descargas de base deste aqüífero. A precipitação média anual da região varia de 1.000 a $2.000 \mathrm{~mm}$ por ano (medições realizadas no período de 1998 a 2009). O menor período de chuvas, da ordem de 96 dias, ocorreu no ano de 2006, sendo que o maior, no ano de 1998, foi de 156 dias. Segundo a classificação de Köppen, trata-se de um clima e subtropical de altitude, do tipo Cfb (MAACK, 1981).

A bacia hidrográfica do Alto Capivari está localizada ao norte da região urbana de Curitiba e é pertencente à bacia do Ribeira do Iguape, agrupada no denominado conjunto hidrográfico do Atlântico Leste. De acordo com Fritzson (2003), a bacia do Capivari apresenta um formato bastante irregular, com 125,19 km² (12.519 ha) e um perímetro de $82,5 \mathrm{~km}$. A bacia apresenta em seu exutório a ETA (Estação de Tratamento de Água da SANEPAR - desativada) de São Dimas, onde rio Capivari apresenta uma largura máxima de 9 metros, sendo a vazão média do rio (com medições feitas nos anos de 1997, 1998 e 1999) de $3,5 \mathrm{~m}^{3} / \mathrm{s}$. Segundo esta autora, a bacia passa para $6^{\mathrm{a}}$ a ordem nas proximidades do exutório e pode ser dividida em duas grandes sub-bacias, correspondentes aos dois maiores rios que compõem a rede de drenagem, o rio Bacaetava e o rio Capivari. O rio Bacaetava é um afluente do rio Capivari, e a sub-bacia Bacaetava ocupa a porção oeste da área estudada; já a sub-bacia do Capivari ocupa porção norte/leste e compreende as nascentes do rio Capivari.

$\mathrm{Na}$ bacia predominam pequenas unidades de agricultura familiar produtoras de hortaliças, milho, feijão e alguns poucos animais criados para consumo próprio. O reflorestamento de bracatinga do nesta bacia é comum, e a atividade mineradora se faz presente com a extração de calcário, que vem se expandindo nos últimos anos e constitui uma importante atividade econômica dos municípios que fazem parte da bacia (municípios de Colombo, Almirante Tamandaré, Bocaiúva do Sul e Rio Branco do Sul). 
Tabela 1 - Medição das vazões em três pontos do rio Capivari.

\begin{tabular}{|c|c|c|c|c|}
\hline \multirow{2}{*}{ Estação hidrométrica } & Localização UTM (metros) & \multicolumn{3}{|c|}{ Vazão (m $\mathbf{3} / \mathbf{h})$} \\
\cline { 3 - 5 } & & $30 / 01 / 09$ & $20 / 03 / 09$ & $12 / 06 / 09$ \\
\hline $\begin{array}{c}\text { Pesque Pague (Rio } \\
\text { Capivari) }\end{array}$ & $\begin{array}{c}686.409 \\
7.206 .207\end{array}$ & $5.652,0$ & $4.014,0$ & $3.769,0$ \\
\hline $\begin{array}{c}\text { Chácara da Luz (Rio } \\
\text { Capivari) }\end{array}$ & $\begin{array}{c}686.409 \\
7.204 .512\end{array}$ & & $5.292,0$ & $4.568,0$ \\
\hline $\begin{array}{c}\text { Chácara Caetanos } \\
\text { (Ribeirão das Onças) }\end{array}$ & 684285 & & 471,00 & 392,00 \\
\hline \multicolumn{2}{|c|}{$*$ Déficit de vazão } & & 807,00 & 407,00 \\
\hline
\end{tabular}

* Equivale a vazão de contribuição de água do compartimento hidrogeológico da Várzea para a bacia do Rio Capivari. Além dessa vazão, existe a descarga retirada dos três poços em operação (da ordem de 300 $\mathrm{m}^{3} / \mathrm{h}$..

Tabela 2 - Vazões dos poços tubulares em produção na Várzea do Capivari.

\begin{tabular}{|c|c|c|c|c|c|c|c|}
\hline \multirow{2}{*}{ Poço } & \multirow{2}{*}{$\begin{array}{c}\text { Localização } \\
\text { UTM } \\
\text { (metros) }\end{array}$} & \multicolumn{3}{|c|}{ Vazão $\left(\mathbf{m}^{3} / \mathbf{h}\right)$} & \multicolumn{3}{|c|}{$\begin{array}{l}\text { Volume mensal explotado } \\
\qquad\left(\mathrm{m}^{3}\right)\end{array}$} \\
\hline & & $30 / 01 / 09$ & $20 / 03 / 09$ & $12 / 06 / 09$ & Jan/09 & Mar/09 & Jun/09 \\
\hline $\begin{array}{l}\text { Poço } 03 \text { (Várzea } \\
\text { do Capivari) }\end{array}$ & $\begin{array}{c}685.763 \\
7.205 .909\end{array}$ & 96,00 & 86,00 & 82,00 & 69.493 & 62.158 & 56.663 \\
\hline $\begin{array}{c}\text { Poço } 04 \text { (Várzea } \\
\text { do Capivari) }\end{array}$ & $\begin{array}{c}686.407 \\
7.205 .345 \\
\end{array}$ & 89,90 & 89,40 & 89,00 & 62.898 & 62.729 & 59.557 \\
\hline $\begin{array}{c}\text { Poço } 05 \text { (Várzea } \\
\text { do Capivari) }\end{array}$ & $\begin{array}{c}686.091 \\
7.204 .781 \\
\end{array}$ & 137,41 & 135,00 & 131,40 & 100.996 & 9.937 & 93.225 \\
\hline \multicolumn{2}{|l|}{ Somatório } & 323,31 & 310,4 & 302,40 & & & \\
\hline
\end{tabular}

A vegetação natural, original da área, de acordo com Veloso (1991), corresponde ao domínio da Floresta Ombrófila Mista (FOM), ou Floresta com Araucária, a qual é exclusiva do Planalto Meridional Brasileiro. Klein e Hatschback (1962), em estudo de fitofisionomia, que abrange a área dessa bacia, baseados num levantamento florístico de 1952, concluíram que os remanescentes da Floresta Ombrófila Mista já eram raros e perturbados pela intervenção humana. Quanto à floresta ciliar, muitas vezes é inexistente, sendo comum a presença de estradas margeando os rios sem a mínima proteção dessa vegetação.

\section{MEDIÇÕES DA VAZÃO DO RIO CAPIVARI NA ÁREA DE ESTUDO}

As vazões do rio Capivari, para efeito do estudo proposto, foram realizadas a montante e a jusante da área onde serão implantados os poçostestes para fins de monitoramento da captação das águas do rio. Esses poços deverão ser contratados pela SANEPAR. A localização desses pontos pode ser visualizada na figura 1 , e os resultados das medições da vazão de cada ponto são apresentados na tabela 1. Os índices pluviométricos, no período das medições, foram cerca de $180 \mathrm{~mm}$ por mês.

As medições realizadas das descargas do rio Capivari, no mês de julho de 2009, apontam, por exemplo, uma diferença de $1.191 \mathrm{~m}^{3} / \mathrm{h}$, incluindo a descarga do ribeirão das Onças, sendo esta vazão da ordem de $392, \mathrm{~m}^{3} / \mathrm{h}$. Neste mesmo período, os três poços existentes na mesma área extraíram uma vazão de $302 \mathrm{~m}^{3} / \mathrm{h}$. Desconsiderando a contribuição do afluente ribeirão das Onças, ainda resta uma descarga de $799 \mathrm{~m}^{3} / \mathrm{h}$. Tendo em conta que as descargas de base dos rios da região é da ordem ordem de $70 \%$ da descarga total, restaria ainda $240 \mathrm{~m}^{3} / \mathrm{h}$ que poderia ser extraída através dos poços a serem implantados na área de estudo. 
Destaque-se que já está definida, nesta área, a existência de estruturas carstificadas através das quais poderá haver a recarga induzida, do rio até os poços projetados. A vazão induzida proporcionará o aumento do potencial de produção do aqüífero, especialmente nos períodos de estiagens quando normalmente a produção dos poços decresce, com o decaimento do nível dinâmico destas unidades de captação. A recarga deverá compensar o nível dinâmico, proporcionando uma maior altura potenciométrica do aqüífero. Este fenômeno deverá reduzir os problemas de ordem geotécnica (acomodação do terreno) e ambiental (redução da descarga de base do rio. As vazões dos poços existentes, são mostrados na tabela 2 .

É interessante destacar que as águas do rio Capivari são classificados como da "Classe I".

\section{REFERÊNCIAS}

AGUIAR, R.L. (1989). Mapeamento geotécnico da área de expansão urbana de São Carlos - SP: contribuição ao planejamento. 2v. $127 \mathrm{p}+14$ mapas. Dissertação de Mestrado Departamento de Geotecnia. Escola de Engenharia de São Carlos, Universidade de São Paulo, São Carlos. 1989.

AQUA BAVARIA GUARANI (2004). Gerenciamento de aqüíferos. Relatório preparado pelo consórcio de consultores alemães sobre a explotação sustentável do Aqüífero Guarani em Ribeirão Preto (SP). Meio Digital.

ARAÚJO, L.M.; FRANÇA, A.B.; POTTER, P.E. (1995). Aqüífero Gigante do Mercosul no Brasil, Argentina, Paraguai, e Uruguai: mapas hidrogeológicos das formações Botucatu, Pirambóia, Rosário do Sul, Buena Vista, Misiones e Tacuarembó. Universidade Federal do Paraná (UFPR) e Petróleo Brasileiro S.A. (Petrobrás), 16p. e anexos.

BTA Engenharia. (1998). Planta planialtimétrica, digitalizada e georreferenciada, em escala 1:10.000 da cidade de São Carlos, com a locação dos poços do SAAE. Arquivo em formato dwg, gravado em CD. 1998.

DAEE - Departamento de Águas e Energia Elétrica. (1974). Estudo de águas subterrâneas - Região Administrativa 6.- Ribeirão Preto. DAEE, São Paulo, 1974, 2 v.

IPT - INSTITUTO DE PESQUISAS TECNOLÓGICAS. (1981). Mapa geológico do Estado de São Paulo (1:500.000).- São Paulo. PT, $2 \mathrm{~V}$.

IPT - INSTITUTO DE PESQUISAS TECNOLÓGICAS. (2004). Diagnóstico da situação atual dos recursos hídricos e estabelecimento de diretrizes técnicas para a elaboração do Plano da Bacia Hidrográfica do Tietê / Jacaré. UGRHI 13. Comitê da Bacia Hidrográfica do Tietê / Jacaré - CBH TJ. Fundo
Estadual de Recursos Hídricos - FEHIDRO. Minuta disponível on line em http://www.sigrh. sp.gov.br. Acesso em 14/11/2004.

GIARDIN, A. \& FACCINI, U. F. (2004). Complexidade hidroestratigráfica e estrutural do Sistema Aqüífero Guarani: abordagem metodológica aplicada ao exemplo de Santa Maria - RS. Rev. Águas Subterrâneas no 18/ Janeiro 2004.

MACHADO, J.L.F.; FACCINI, U. F. (2004). Compartimentação Estrutural do SAG no Rio Grande do Sul: características hidrodinâmicas e hidroquímicas (em preparação).

MACHADO, J.L.F., (2005). A verdadeira face do Aqüífero Guarani: Mitos e Fatos. ABAS XIV Encontro Nacional de Perfuradores de Poços. II Simpósio de Hidrogeologia do Sudeste

MACHADO, J.L.F. e UBIRATAN, F.F., (2005). Influência dos falhamentos regionais na estruturação do Sistema Aqüífero Guarani no Estado do Rio Grande do Sul. Disponível online em http://www.cprm.gov.br/rehi/congresso/ falha_reg.pdf

PERRONI, J.C.A. (2005). Avaliação do consumo de energia elétrica para produção de água - $\mathrm{O}$ caso do abastecimento público da cidade de São Carlos - SP. 145p. Dissertação (Mestrado) - Escola de Engenharia de São Carlos, Universidade de São Paulo.

PFEIFFER, S.C. e CHAUDHRY, F.H. (1993). Caracterização da qualidade das águas do Aqüífero Botucatu na região urbana de São Carlos SP. In: Congresso Brasileiro de Recursos Hídricos do Cone Sul 10., 1993. ABRH Associação Brasileira de Recursos Hídricos. Gramado - RS. p.510-519. 1993.

REBOUÇAS,A.C., (1976), Recursos hídricos da Bacia do Paraná. São Paulo, Tese de Livre Docência, IGc/USP, 143p., 2 mapas.

ROCHA, G. A. (1996). Mega reservatório 
de água subterrânea do Cone Sul: bases para uma política de desenvolvimento e gestão: Contribuiçao ao Seminário e Workshop Internacional do Aqüífero Gigante do Mercosul, Curitiba, Paraná, Brasil. Universidade Federal do Paraná (Brasil), Universidad de la República Oriental del Uruguay (Uruguay), Universidad Nacional de La Plata (Argentina), SENASA, International Development Research Centre (Canada), 27p (texto de divulgaçao no evento).

SILVA, R.B.G. (1983). Estudo hidroquímico e isotópico das águas subterrâneas do Aqüífero Botucatu no Estado de São Paulo. Tese de Doutoramento, USP-IG, (133 pg), São Paulo. 1983.

\section{AGRADECIMENTOS}

Os autores agradecem a colaboração, sugestões e orientações da equipe de engenheiros do SAAE - São Carlos, liderado pelo Prof. Dr. Jurandyr Povinelli - Diretor Superintendente. 